\title{
Alkali Metasomatism and Th-REE Mineralization in the Choghart deposit, Bafq district, Central Iran
}

\author{
Khalegh Khoshnoodi ${ }^{1,2, *}$, Mehrdad Behzadi ${ }^{1}$, Mohammad Gannadi-Maragheh ${ }^{2}$ and Mohammad Yazdi ${ }^{1}$ \\ 1 University of Shahid Beheshti, Faculty of Earth Science, Department of Geology, Tehran, Islamic Republic of Iran; ("corresponding author: khoshnoodi78@gmail.com) \\ ${ }^{2}$ Atomic Energy Organization of Iran, Nuclear Science and Technology Research Institute, Material and Nuclear Fnel Research School, Tehran, Islamic Republic of Iran
}

doi: $10.4154 / g c .2017 .03$

\author{
Article history: \\ Manuscript received May 23, 2016 \\ Revised manuscript accepted February 09, 2017 \\ Available online February 25, 2017
}

\begin{abstract}
The Choghart iron oxide-apatite (IOA) deposit is located $124 \mathrm{~km}$ southeast of Yazd, in the Bafq district within the Central Iranian microcontinent. The Choghart deposit is hosted by the rhyolitic rocks of the Early Cambrian volcano-sedimentary sequence (the Esfordi formation). Both host rocks and the orebodies are crosscut by diabase dykes. Tectonically, the Choghart rhyolites represent the continental margin setting and the Choghart diabase dykes formed in the back-arc basin environment, respectively, indicating that the evolution of the Bafq district is associated with subduction of Palaeotethys oceanic crust beneath the Central Iranian microcontinent followed by formation of continental arc related granitoids and rhyolites and then formation of backarc basin diabase dykes. Similar to the other subduction-related rhyolites, the Choghart rhyolite is enriched in Th and LREE compared to $\mathrm{Ta}, \mathrm{Nb}$, and HREE.

The main host minerals of Th and REE in the Th-REE mineralization zone are thorite and sphene. Albitization is the most important alteration aspect related to Th-REE mineralization (mainly Th, $\mathrm{La}, \mathrm{Ce}, \mathrm{Nd}$, and $\mathrm{Y}$ ). In addition to albite, Th-REE mineralization is associated with actinolite, augite, diopside, minor microcline and orthoclase, plus magnetite, calcite, pyrite, rutile, and minor amounts of chalcopyrite. The negative Eu anomaly in Th mineralization zone, as well as the paragenetic occurrence of magnetite, pyrite and chalcopyrite with thorite suggest that Th-REE mineralization formed in relatively reduced condition. The presence of paragenetic calcite accompanied by thorite and sphene in the Th-REE mineralization zone indicates that Th and REE were likely transported by the carbonate complexes in the mineralizing fluids. The similarity between the chondrite-normalized REE patterns of the host rhyolite and the Th-REE mineralization zone suggests that post-magmatic driven fluids of continental margin rhyolitic magma played an important role in Th-REE mineralization.
\end{abstract}

Keywords: Alkali Metasomatism, Th-REE Mineralization, Choghart (IOA) deposit ing such metals and the distribution of the alkaline metasomatic rocks. U-Mo mineralization in the Narigan ore deposit is possesses, genetically, a granite related origin as an exception (IAEA, 2014) and it is not related to metasomatic processes (DAHLKAMP, 2009).

Metasomatic processes are proposed as performing geochemical roles in the concentration of REE-U-Th bearing minerals in some areas of the world (e.g. the Kirovograd- Krivoi Rog district of the Ukraine, Lagoa Real in Brazil and the Beaverlodge district of Canada, WILDE (2013). Na-metasomatism, among other types of metasomatic processes, are particularly effective in the concentration of such elements. This characteristic of metasomatism is marked by Na-bearing minerals, which are clearly in replacement relationships with primary magmatic minerals (PIRAJNO, 2009). The metasomatic and hydrothermal processes that occur with aqueous solutions, are the only endogenic processes in which the content of radioactive elements and primarily uranium reach economic grades TITAYEVA (1994). The rocks affected by this type of metasomatism were first described as Nagranites by TANATAR (1925) or as syenites by FELDMAN (1926). There has been a continuous interest in the association of Th, $\mathrm{U}$ and REE mineralization, and this type of metasomatism is related to the importance of albitization in the mineralization of radioactive elements. According to KINNAIRD (1985), Naenrichment is accompanied by concentrations of $\mathrm{Fe}, \mathrm{U}, \mathrm{Th}, \mathrm{Zr}$,

$\mathrm{Nb}, \mathrm{Sn}, \mathrm{Zn}$ and HREE. Na-metasomatised rocks also tend to be ore deposits and also the correlation between the areas compris- 
enriched in $\mathrm{Rb}, \mathrm{Th}, \mathrm{Nb}, \mathrm{La}, \mathrm{Ce}, \mathrm{Hf}, \mathrm{Zr}$, and $\mathrm{Y}$ with respect to $\mathrm{K}$ metasomatised rocks. The mineralization of natural radioactive elements controlled by the occurrence and development of the albitites is well studied in some localities such as the central Ukraine (CUNEY et al., 2012) and the Uranium City region in Canada (DAHLKAMP, 1993). High-temperature hydrothermal Th deposits are characterized by metasomatic replacements, accompanied by amphibolitization, aegirinization, biotitization, greisenization and filled open cavities (TITAYEVA, 1994). Obtained apatite ages confirm that IOA and the apatite-rich rocks (apatites) of the Bafq district formed coevally with the Early Cambrian magmatic (-metasomatic) events STOSCH et al. (2011). Alkali-metasomatism in the Chogart iron oxide-apatite (IOA) deposit occurred in peripheral alteration zones of the iron orebody.

It is observed by ground radiometric surveys using an RS-230 spectrometer that the radioactive anomaly of Th occurs at the margin of the Fe-orebody. Since no previous study has worked on Th-REE mineralization, the aim of this paper is to define the mineralogy of Th-REE bearing mineral assemblages and the role of alteration/s and metasomatic processes in their genesis.

\section{GEOLOGICAL SETTING OF BAFQ DISTRICT}

The geological setting of the Bafq district is described by RAJABI et al. (2015). The crustal domain referred to as the Central Iranian microcontinent is a composite of three major structural zones, from E to W (ALAVI, 1991), the Lut, Tabas, and Yazd blocks (Figure 1a, b). The boundaries are defined by regionalscale faults (Figure 1). In addition, there is the Posht-e-Badam Block (ALAVI, 1991), a fault-bound, variably deformed and metamorphosed complex of supracrustal rocks that separates the
Tabas and Yazd blocks (Figure 1). The Posht-e-Badam Block represents the area surrounded by three major fault systems (ALAVI, 1991) including the Chapedony, Kalmard and Kuhbanan faults. A Precambrian crystalline basement and Early Cambrian to Tertiary sedimentary cover are exposed in the block (FOSTER \& JAFARZADEH, 1994).

The Precambrian basement consists of medium- to highgrade metamorphic rocks, Late Neoproterozoic in age, grouped in the Boneh-Shurow and Posht-e-Badam complexes (Figure 2; RAJABI, 2008; RAMEZANI \& TUCKER, 2003). The bulk of the Posht-e-Badam complex consists of a variable association of greenstones, schists, meta-greywackes, marbles, gneisses, amphibolites, pyroxenites, serpentinites, meta-basalts and conglomerates (HAGHIPOUR \& PELISSIER, 1968). This complex is exposed west of the Posht-e-Badam Fault (Figure 2) and is severely disrupted by granitic plutons of Triassic age (RAMEZANI \& TUCKER, 2003). The Boneh-Shurow complex, which is the most widely exposed metamorphic unit, crops out east of the Poshte-Badam Fault (Figure 2; HAGHIPOUR \& PELISSIER, 1968). This complex is approximately $2000 \mathrm{~m}$ thick and is composed of a variety of metamorphic rocks, including quartz-feldspathic gneisses, green mica-schists and amphibolites (AGHANABATI, 2008). Zircon $\mathrm{U} / \mathrm{Pb}$ dating of this complex indicates an age of 602-617 Ma (RAMEZANI \& TUCKER, 2003). The BonehShurow complex is covered by a 2000-m-thick sequence of greywackes, quartzites and quartzitic schists, marbles, amphibolites, gneiss, slaty-shales, basaltic lavas, sandstones and arkosic arenites, argillites, tuffaceous rocks and limestones belonging to the Tashk Formation, of Late Neoproterozoic to Early Cambrian age,

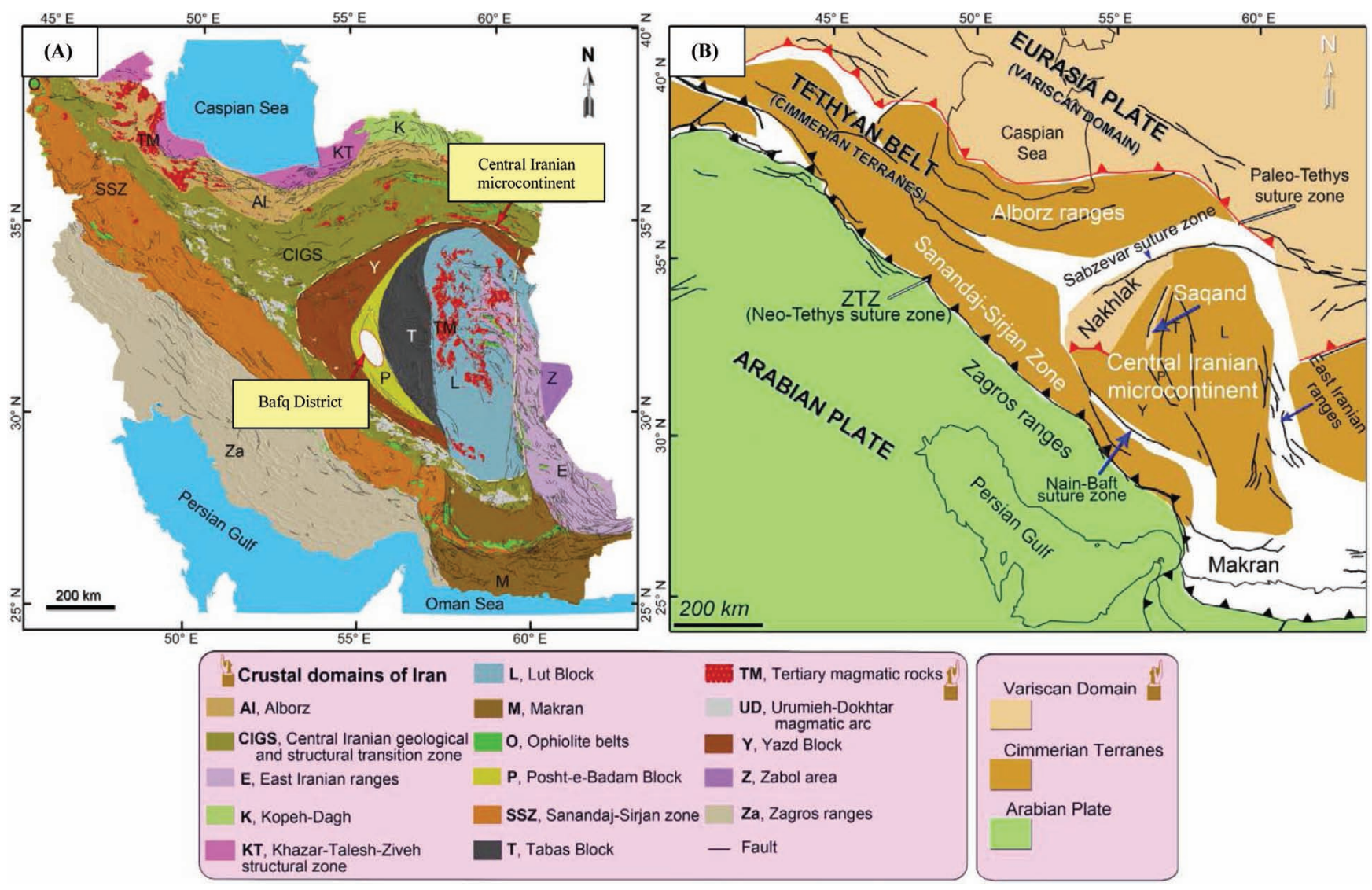

Figure 1. (A) Simplified structural map of Iran (AGHANABATI, 1998) and location of the Bafq district in the Posht-e-Badam Block; (B) Eastern part of the Terranes map of the western Tethysides (RAJABI et al., 2012; modified by after STAMPFLI, 2009; according to BAGHERI \& STAMPFLI, 2008). Note the location of the Iran Plate (Iranian Cimmerian terranes) between the Variscan domain in the north and the Arabian Plate in the southwest (ZTZ: Zagros Thrust Zone). 




Figure 2. Simplified geological map of the Bafq district in the Posht-e-Badam Block, (modified after HAGHIPOUR, 1977; KARGARANBAFGHI et al., 2012; RAMEZANI \&TUCKER, 2003; RAJABI et al., 2015). Geochronological data from RAMEZANI \& TUCKER (2003) and KARGARANBAFGHI et al. (2012).

(RAMEZANI \& TUCKER, 2003) that partly metamorphosed to greenschist facies.

During the Early Cambrian, granitic plutons intruded the Precambrian sequence of the Tashk Formation, and felsic to intermediate volcanic and volcano-sedimentary rocks of the Early
Cambrian volcano-sedimentary sequence (ECVSS) were deposited. The 2000-2500 m thick ECVSS unconformably overlies the clastic sedimentary and tuffaceous rocks of the Tashk Formation. This contact is well exposed to the W and SW of the Narigan area. The ECVSS has also been termed the Cambrian Volcano-Sedi- 
mentary Unit (CVSU), Rizu-Desu series and Esfordi Formation, in different places between the Posht-e-Badam and Kerman areas (HAGHIPOUR, 1977; HUCKRIEDE et al., 1962; RAMEZANI \& TUCKER, 2003; SAMANI, 1993). The ECVSS consists of an unmetamorphosed sequence of interlayered micro-conglomerates, sandstones, mafic to felsic volcanic rocks, pyritic black silt- stones and shales, volcanoclastic beds and tuffaceous shales, dolomites and dolomitic limestones (HUCKRIEDE et al., 1962; RAJABI, 2012; RAMEZANI \& TUCKER, 2003). This sequence is the host of the most important iron oxide-apatite (IOA) (DALIRAN, 2002), Fe-Mn and SEDEX Zn-Pb deposits of Iran (Figure 2). Iron oxide-apatite (IOA) deposits, often referred to as
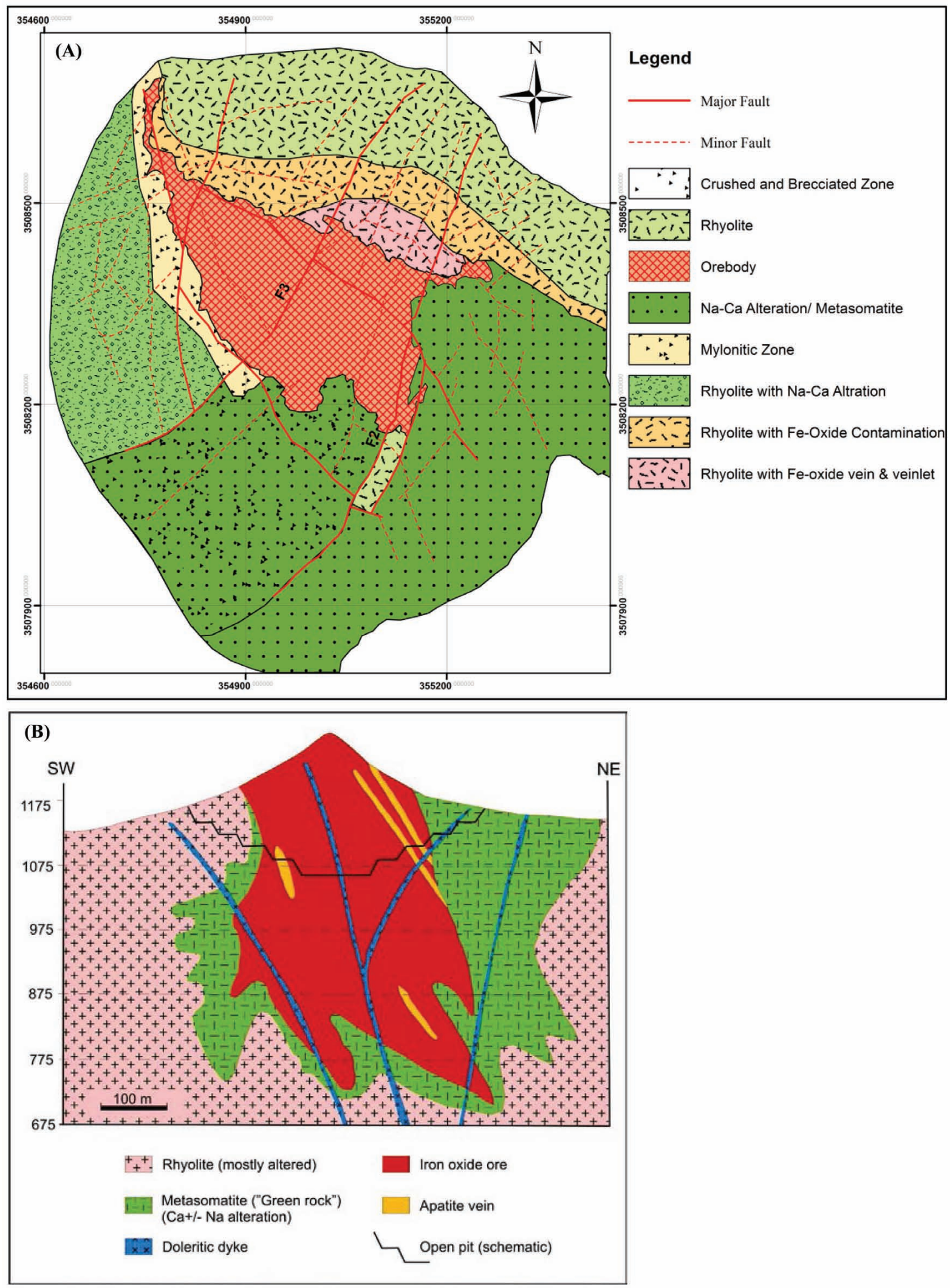

Figure 3. (A) Simplified geological map of the ore body of the Choghart deposit (pit face, 2011; modified after DEHGHAN, 2011); (B) Simplified geological cross section of the Choghart deposit (modified after FOSTER \& JAFARZADEH, 1994). 
Kiruna-type iron ore deposits, are known to have formed from the Proterozoic to the Tertiary. They are commonly associated with calc-alkaline volcanic rocks and regional- to deposit-scale metasomatic alteration (STOSCH et al., 2011).

\section{GEOLOGY OF THE CHOGHART DEPOSIT}

The main roughly vertical, discordant, pipe-shaped magnetiteapatite orebody at Choghart, plunging $73^{\circ} \mathrm{NNW}$, has been explored to a depth of $600 \mathrm{~m}$, where it seems to interfinger with intrusive metasomatized and fragmented wall-rock. The thickness of the metasomatic zone differs widely. The orebody is hosted by volcanic members (rhyolitic to rhyodacitic in composition, as well as so-called quartz albitophyre) of the Infracambrian Esfordi Formation (MOORE \& MODABBERI, 2003).

It is enveloped by metasomatic rocks with variable thickness. The ore body is crosscut by both diabase dykes and N-S trending normal faults. The iron concentration is not uniform throughout the ore body: the Fe content in the centre of the deposit is greater than $65 \%$ whereas it decreases to $45-20 \%$ towards the margins (MOORE \& MODABBERI, 2003). The ore body is mostly surrounded by sodic-calcic hydrothermally altered rocks (Figure 3a, b), with minor albitite (5-30 cm wide). The $\mathrm{P}_{2} \mathrm{O}_{5}$ content is very low $(<0.2 \%)$ and it is enriched in the N-NE of the deposit. N-S, NW-SE and NE-SW trending normal faults cut each other and the ore body. The most well-known outstanding feature is the voluminous district-scale sodic-calcic alteration that developed in volcanic hostrocks. The $\mathrm{Na}-\mathrm{Ca}$ alteration is enveloped as actinolite, apatite, magnetite, haematite, sodic plagioclase, chlorite, with or without epidote. Within the pervasively $\mathrm{Na}-\mathrm{Ca}$ altered rhyolite and volcanoclastic rocks, there are locally patches with intense $\mathrm{Na}$ alteration with veins and veinlets of albite and a brecciated texture (TAGHIPOUR et al. 2013). Apatite is the most abundant gangue at Choghart. It is a distinctive, transparent, yellow-green fluor-apatite. Fine and coarse-grained apatite occur in

Table 1. Major and trace elements (REE, HFSE, LILE) of the felsic and basic rocks of the Bafq district (major oxides in percent and minor and trace elements in ppm; Rhy: Rhyolite, Dia: Diabase, Rhyd: Rhyodacite, Dac: Dacite). Detection limit for major and minor elements $<10 \mathrm{ppm}$ and for trace element $<0.1 \mathrm{ppm}$. ${ }^{\mathrm{R}}=\mathrm{RAJABI}$ et al., 2015; R\&T= RAMEZANI \& TUCKER, 2003; KH= Our research; M: MIRZAEI BENI, 2014; MT= MOHAMMAD TORAB, 2008

\begin{tabular}{|c|c|c|c|c|c|c|c|c|c|c|c|c|}
\hline Sample & Rock & Ref.* & Locality & $\mathrm{SiO}_{2}$ & $\mathrm{TiO}_{2}$ & $\mathrm{Al}_{2} \mathrm{O}_{3}$ & $\mathrm{FeOt}$ & $\mathrm{MnO}$ & $\mathrm{MgO}$ & $\mathrm{CaO}$ & $\mathrm{Na}_{2} \mathrm{O}$ & $\mathrm{K}_{2} \mathrm{O}$ \\
\hline ES7 & Rhy & MT & Esfordi & 73.08 & 0.212 & 11.64 & 1.575 & 0.024 & 0.21 & 0.478 & 0.26 & 8.465 \\
\hline ES9 & Rhy & MT & Esfordi & 72.22 & 0.35 & 15.02 & 0.972 & 0.007 & 1.31 & 0.228 & 0.22 & 4.906 \\
\hline B3-S1 & Rhy & MT & Esfordi & 61.95 & 0.103 & 10.49 & 2.952 & 0.023 & 7.75 & 3.62 & 0.27 & 6.456 \\
\hline B35-S1 & Rhy & MT & Esfordi & 63.29 & 0.145 & 9.72 & 2.979 & 0.017 & 8.55 & 3.424 & 0.44 & 5.254 \\
\hline B43-S1 & Rhy & MT & Esfordi & 62.82 & 0.205 & 10.43 & 4.869 & 0.041 & 5.05 & 3.886 & 0.34 & 6.059 \\
\hline MA1 & Rhy & MT & Chador-Malu & 65.94 & 0.213 & 10.77 & 5.49 & 0.059 & 0.93 & 1.834 & 0.27 & 8.894 \\
\hline Ry-1 & Rhy & $M$ & Se-Chahun & 77.17 & - & 10.98 & 2.14 & - & 0.7 & 0.73 & 4.76 & 3.32 \\
\hline Ry-2 & Rhy & M & Se-Chahun & 78.35 & - & 9.03 & 3.15 & - & 2.6 & 0.52 & 2.07 & 3.88 \\
\hline Ry-3 & Rhy & $M$ & Se-Chahun & 74.15 & - & 11.81 & 2.7 & - & 0.9 & 1.5 & 5.13 & 3.58 \\
\hline Ry-4 & Rhy & M & Se-Chahun & 76.66 & - & 9.9 & 3.4 & - & 2.81 & 0.58 & 2.35 & 3.9 \\
\hline 6 & Dia & $\mathrm{R}$ & Chahmir & 47.61 & 3.7 & 16.14 & 12.82 & 0.19 & 6.37 & 4.78 & 4.29 & 2.01 \\
\hline 7 & Dia & $\mathrm{R}$ & Koushk & 46.75 & 3.29 & 15.75 & 13.89 & 0.3 & 6.4 & 4.88 & 4.1 & 2.29 \\
\hline 9 & Dia & $\mathrm{R}$ & Narigan & 51.73 & 2.37 & 13.76 & 11.26 & 0.21 & 7.89 & 7.49 & 2.9 & 0.77 \\
\hline 10 & Dia & $\mathrm{R}$ & Narigan & 52.53 & 2.25 & 13.39 & 11.03 & 0.2 & 7.76 & 7.34 & 3.09 & 0.8 \\
\hline 16 & Dia & J & Narigan & 44 & 3.21 & 13.35 & 12.83 & 0.14 & 8.62 & 6.16 & 3.53 & 1.51 \\
\hline 21 & Rhy & R\&T & Duzakh-Darreh & 79.06 & 0.24 & 11.95 & 0.13 & 0.01 & 0.19 & 0.45 & 6.22 & 1.46 \\
\hline 22 & Dac & $R \& T$ & Chahgaz & 67.05 & 0.81 & 13.23 & 6.48 & 0.05 & 0.74 & 1.76 & 6.48 & 1.7 \\
\hline 26 & Rhyd & $\mathrm{R}$ & Narigan & 72.62 & 0.24 & 13.66 & 1.59 & 0.12 & 0.16 & 1.7 & 3.07 & 6.62 \\
\hline 27 & Rhyd & $\mathrm{R}$ & Narigan & 73.97 & 0.21 & 12.68 & 1.43 & 0.11 & 0.19 & 1.48 & 3.38 & 6.34 \\
\hline 28 & Rhy & $\mathrm{R}$ & Koushk & 74.81 & 0.24 & 11.51 & 2.55 & 0.03 & 0.54 & 1.16 & 0.21 & 8.64 \\
\hline 29 & Rhy & $\mathrm{R}$ & Koushk & 70.59 & 0.27 & 13.2 & 3.84 & 0.08 & 0.51 & 1.32 & 0.3 & 9.34 \\
\hline 31 & Rhy & $\mathrm{R}$ & Chahmir & 71.21 & 0.21 & 12.51 & 3.2 & 0.51 & 0.5 & 1.12 & 0.31 & 9.16 \\
\hline 32 & Rhy & $\mathrm{R}$ & Chahmir & 73.8 & 0.2 & 13.14 & 1.83 & 0.04 & 0.56 & 1.01 & 0.23 & 8.59 \\
\hline 38 & Rhy & $\mathrm{R}$ & Chahmir & 78.38 & 0.16 & 10.9 & 1.2 & 0.03 & 0.52 & 1.44 & 4.63 & 2.37 \\
\hline 45 & Dia & $\mathrm{R}$ & Zarigan & & & & & & & & & \\
\hline KH-001 & Dia & $\mathrm{KH}$ & Choghart & 54.35 & 1.43 & 9.04 & 9.50 & 0.03 & 7.56 & 1.12 & 0.76 & 1.98 \\
\hline KH-008 & Dia & $\mathrm{KH}$ & Choghart & 53.5 & 2.15 & 14.26 & 14.85 & 0.12 & 6.63 & 8.39 & 2.52 & 2.00 \\
\hline KH-009 & Rhy & $\mathrm{KH}$ & Choghart & 78.37 & 0.11 & 13.32 & 4.31 & 0.012 & 3.81 & 1.95 & 4.82 & 1.55 \\
\hline KH-010 & Rhy & $\mathrm{KH}$ & Choghart & 83.06 & 0.22 & 6.39 & 1.69 & 0.006 & 0.08 & 0.42 & 6.30 & 0.91 \\
\hline KH-011 & Rhy & $\mathrm{KH}$ & Choghart & 83.45 & 0.22 & 7.10 & 2.84 & 0.004 & 0.44 & 0.66 & 6.67 & 0.90 \\
\hline $\mathrm{KH}-059$ & Rhy & $\mathrm{KH}$ & Choghart & 81.08 & 0.21 & 12.72 & 1.93 & 0.008 & 0.86 & 1.25 & 6.55 & 1.51 \\
\hline KH-071 & Dia & $\mathrm{KH}$ & Choghart & 55.81 & 4.36 & 15.58 & 13.96 & 0.1 & 7.58 & 10.12 & 4.28 & 1.83 \\
\hline KH-072 & Rhy & $\mathrm{KH}$ & Choghart & 82.5 & 0.21 & 14.52 & 2.55 & 0.019 & 0.90 & 1.88 & 7.86 & 0.41 \\
\hline KH-096 & Rhy & $\mathrm{KH}$ & Choghart & 83.43 & 0.16 & 9.83 & 1.09 & 0.015 & 0.46 & 0.74 & 7.06 & 0.97 \\
\hline KH-097 & Rhy & $\mathrm{KH}$ & Choghart & 83.92 & 0.22 & 12.56 & 1.54 & 0.007 & 0.20 & 0.57 & 7.51 & 0.81 \\
\hline KH-098 & Rhy & $\mathrm{KH}$ & Choghart & 80.61 & 0.33 & 13.45 & 2.21 & 0.005 & 0.45 & 0.61 & 7.25 & 1.20 \\
\hline KH-099 & Rhy & $\mathrm{KH}$ & Choghart & 82.63 & 0.21 & 12.32 & 1.36 & 0.014 & 0.08 & 2.39 & 7.65 & 0.16 \\
\hline $\mathrm{KH}-100$ & Rhy & $\mathrm{KH}$ & Choghart & 83.22 & 0.25 & 12.01 & 1.48 & 0.004 & 0.40 & 0.40 & 6.60 & 1.27 \\
\hline KH-101 & Dia & $\mathrm{KH}$ & Choghart & 48.53 & 4.84 & 15.39 & 13.69 & 0.18 & 6.56 & 9.90 & 3.44 & 2.20 \\
\hline $\mathrm{KH}-102$ & Dia & $\mathrm{KH}$ & Choghart & 54.96 & 3.08 & 17.13 & 13.18 & 0.18 & 4.42 & 7.35 & 5.84 & 1.85 \\
\hline
\end{tabular}


Table 1. continued

\begin{tabular}{|c|c|c|c|c|c|c|c|c|c|c|c|c|c|}
\hline Sample & $\mathrm{P}_{2} \mathrm{O}_{5}$ & $\mathrm{La}$ & $\mathrm{Ce}$ & $\mathrm{Pr}$ & $\mathrm{Nd}$ & $\mathrm{Sm}$ & $\mathrm{Eu}$ & $\mathrm{Gd}$ & $\mathrm{Tb}$ & Dy & $\mathrm{Ho}$ & $\mathrm{Er}$ & $\mathrm{Tm}$ \\
\hline ES7 & 0.022 & 30.3 & 57 & $<50$ & 17 & 2.5 & 0.7 & & $<0.5$ & & & & \\
\hline ES9 & 0.072 & 1.4 & 5 & $<50$ & $<5$ & 0.4 & $<0.2$ & & $<0.5$ & & & & \\
\hline B3-S1 & 0.626 & 129 & 221 & $<50$ & 106 & 16.1 & 2.1 & & 2.3 & & & & \\
\hline B35-S1 & 1.071 & 147 & 324 & 57 & 108 & 20.9 & 3.1 & & 2.8 & & & & \\
\hline B43-S1 & 0.487 & 71 & 138 & $<50$ & 60 & 11.3 & 1.4 & & 1.7 & & & & \\
\hline MA1 & 0.056 & 34.2 & 105 & $<50$ & 43 & 12.9 & 2 & & 1.8 & & & & \\
\hline Ry-1 & 0.03 & 40.5 & 73.65 & 9.8 & 34.2 & 7.1 & 1.3 & 5.3 & 0.8 & 4.3 & 0.8 & 2.1 & 0.3 \\
\hline Ry-2 & 0.06 & 38.4 & 67.14 & 8.7 & 29.7 & 6 & 1.1 & 4.4 & 0.9 & 4.1 & 0.8 & 2 & 0.3 \\
\hline Ry-3 & 0.05 & 39.5 & 70.54 & 9.16 & 31.59 & 6.58 & 1.21 & 4.84 & 0.88 & 4.63 & 0.88 & 2.25 & 0.32 \\
\hline Ry-4 & 0.05 & 36.2 & 64.64 & 8.39 & 28.93 & 6.03 & 1.11 & 4.44 & 0.81 & 4.26 & 0.81 & 2.07 & 0.29 \\
\hline 6 & 0.61 & 33 & 65.2 & 7.7 & 32.2 & 7.8 & 2.6 & 7.8 & 1.1 & 5.6 & 1 & 2.5 & 0.3 \\
\hline 7 & 0.8 & 30.1 & 63 & 7.5 & 30 & 7.7 & 2.5 & 7.7 & 1 & 5.4 & 0.9 & 2.3 & 0.3 \\
\hline 9 & 0.34 & 22.7 & 49.9 & 6.6 & 27.3 & 6.5 & 2.1 & 6.4 & 1 & 5.3 & 1 & 2.5 & 0.4 \\
\hline 21 & 0.08 & 30.2 & 57.2 & 6.3 & 22.4 & 4.1 & 0.9 & & 0.7 & & & & \\
\hline 22 & 0.21 & 57.8 & 135.2 & 16.7 & 67 & 17.8 & 3.9 & & 3.3 & & & & \\
\hline 26 & 0.05 & 9.2 & 19.1 & 2.3 & 8.5 & 1.7 & 0.3 & 1.8 & 0.3 & 2.1 & 0.5 & 1.6 & 0.3 \\
\hline 27 & 0.05 & 9 & 17 & 2.1 & 7 & 1.5 & 0.2 & 1.5 & 0.3 & 1.8 & 0.4 & 1.3 & 0.2 \\
\hline 28 & 0.03 & 20.9 & 43 & 4.9 & 17.5 & 3.4 & 0.7 & 4.9 & 1 & 7.5 & 1.8 & 5.8 & 0.9 \\
\hline 29 & 0.1 & 17 & 38 & 4.8 & 15 & 3.1 & 0.6 & 4.5 & 0.9 & 7.3 & 1.7 & 5.3 & 0.9 \\
\hline 31 & 0.88 & 14 & 31 & 4.3 & 13 & 3 & 0.6 & 4.1 & 0.8 & 5.5 & 1.5 & 5.1 & 0.7 \\
\hline 32 & 0.4 & 11 & 27 & 3.9 & 11 & 2.8 & 0.5 & 3.9 & 0.7 & 5 & 1.3 & 4.9 & 0.6 \\
\hline 45 & & 56.3 & 113 & 13.3 & 48.1 & 8.9 & 2.8 & 6.9 & 1 & 5 & 0.9 & 2.3 & 0.3 \\
\hline KH-001 & 0.32 & 31.25 & 65.52 & 8.06 & 37.30 & 5.04 & 2.02 & 5.04 & 0.91 & 3.02 & 0.50 & 2.02 & 0.30 \\
\hline KH-008 & 0.45 & 27.86 & 65.02 & 7.22 & 37.15 & 7.22 & 2.06 & 7.22 & 0.93 & 4.13 & 0.83 & 2.06 & 0.31 \\
\hline KH-009 & 0.02 & 8.92 & 30.72 & 2.97 & 1119.8 & 1.98 & 0.30 & 1.98 & 0.30 & 1.98 & 0.59 & 1.98 & 0.30 \\
\hline KH-059 & 0.01 & 23.23 & 62.62 & 5.05 & 27.27 & 1.01 & 0.40 & 4.04 & 0.20 & 2.02 & 0.51 & 1.01 & 0.10 \\
\hline KH-071 & 0.54 & 5.90 & 10.82 & 0.98 & 5.90 & 0.98 & 0.39 & 1.97 & 0.20 & 0.98 & 0.20 & 0.98 & 0.10 \\
\hline KH-072 & 0.01 & 71.86 & 159.68 & 18.96 & 99.80 & 14.97 & 4.99 & 19.96 & 2.00 & 7.98 & 2.00 & 3.99 & 0.50 \\
\hline KH-096 & 0.01 & 6.97 & 10.95 & 1.99 & 5.97 & 1.00 & 0.40 & 1.00 & 0.10 & 0.40 & 0.10 & 0.50 & 0.10 \\
\hline KH-097 & 0.01 & 5.95 & 9.92 & 0.99 & 4.96 & 0.99 & 0.40 & 0.69 & 0.10 & 0.50 & 0.10 & 0.30 & 0.10 \\
\hline KH-098 & 0.00 & 2.94 & 4.91 & 0.98 & 4.91 & 0.98 & 0.39 & 1.96 & 0.20 & 1.96 & 0.29 & 0.98 & 0.10 \\
\hline KH-099 & 0.00 & 2.90 & 4.84 & 0.58 & 3.87 & 0.97 & 0.39 & 1.93 & 0.19 & 0.97 & 0.19 & 0.87 & 0.19 \\
\hline $\mathrm{KH}-100$ & 0.01 & 2.96 & 7.88 & 0.99 & 3.94 & 0.39 & 0.10 & 0.59 & 0.10 & 0.49 & 0.10 & 0.39 & 0.10 \\
\hline KH-101 & 0.40 & 52.31 & 110.66 & 12.07 & 51.31 & 8.05 & 3.02 & 10.06 & 1.01 & 8.05 & 1.01 & 4.02 & 0.50 \\
\hline KH-102 & 1.03 & 79.70 & 174.96 & 15.55 & 71.93 & 12.64 & 4.86 & 14.58 & 0.97 & 6.80 & 0.97 & 2.92 & 0.10 \\
\hline
\end{tabular}

varying proportions with magnetite, and apatite-bearing magnetite is the most abundant ore type at Choghart. At least two generations of apatite are discernible. The first, which is contemporaneous with the main phase of iron oxide formation, displays euhedral crystals ranging in size from a few millimetres to a few centimetres in diameter. It is intimately intergrown with magnetite. The second generation occurs as subhedral to anhedral crystals in lenses, dykes, and veinlets of varying size and thickness, which cut the magnetite-apatite ore (MOORE \& MODABBERI, 2003).

Pyrite and quartz are distributed quite evenly in the orebody, either as solid inclusions in primary magnetite grains or as welldeveloped crystals in the orebody and the adjacent country rock. Some magnetite crystals are cemented by quartz and vice versa, indicating alternation of magnetite and quartz mineralization. Calcite, dolomite, secondary haematite and talc occur throughout the orebody as veinlets and cementing material of oxidized ore. Rutile and goethite are probably the result of the total transfor- mation of the earlier formed martite (MOORE \& MODABBERI, 2003).

The Th-REE enriched zone occurs within the south-eastern margin of the Fe-orebody between the F5 and F6 faults and it also cuts the sodic-calcic metasomatism/alteration as well as the host rhyolite (Figure 3a). The radioactive anomaly of thorium is observed in the margin of the Fe-orebody by ground radiometric and spectrometric surveys using an RS-230 spectrometer. Chemical analyses of samples of this zone show Th-REE mineralization.The hydrothermal breccia and albitization (pink in colour), are both associated with Th-REE mineralization shown in Figure 4a, b. Carbonate-silica veins and veinlets cross cut the host rock, the Fe-orebody and Th-REE mineralization zone which indicates that they are formed after the Th-REE mineralization.

\section{MATERIAL AND METHODS}

Thirty-five samples were collected for petrographic, ore microscopic and geochemical studies from the Th-REE mineralization 
Table 1. continued

\begin{tabular}{|c|c|c|c|c|c|c|c|c|c|c|c|c|c|}
\hline Sample & $\mathrm{Yb}$ & $\mathrm{Lu}$ & $\mathrm{Nb}$ & Ta & $\mathrm{Zr}$ & $\mathrm{Hf}$ & $\mathrm{Nb}$ & Ta & $\mathrm{Pb}$ & $Y$ & $\mathrm{Zr}$ & Th & U \\
\hline ES7 & 2 & 0.44 & 4 & $<0.5$ & 188 & 5 & .375 & $<0.5$ & $<3$ & 9 & 188 & 19.5 & 6.8 \\
\hline ES9 & 0.9 & 0.25 & 6 & $<0.5$ & 227 & 5 & .375 & $<0.5$ & $<3$ & $<3$ & 227 & 2.5 & 1.5 \\
\hline B3-S1 & 5.8 & 0.86 & $<2$ & $<0.5$ & 181 & 6 & .375 & $<0.5$ & $<3$ & 47 & 181 & 14.9 & 1.2 \\
\hline B35-S1 & 7.7 & 1.16 & 2 & $<0.5$ & 195 & 4 & .375 & $<0.5$ & $<3$ & 124 & 195 & 14.9 & 1.9 \\
\hline B43-S1 & 6.1 & 0.91 & $<2$ & $<0.5$ & 175 & 5 & .375 & $<0.5$ & 3 & 54 & 175 & 18.8 & 4.7 \\
\hline MA1 & 3.2 & 0.41 & $<2$ & 0.6 & 159 & 5 & .6 & 0.6 & 11 & 38 & 159 & 6 & 1.5 \\
\hline Ry-1 & 2 & 0.4 & 3.07 & 0.4 & 58.6 & 2.35 & .4 & 0.4 & 1.43 & 21.2 & 58.6 & 12.3 & 2.1 \\
\hline Ry-2 & 2.1 & 0.3 & 5.18 & 0.4 & 62.8 & 2.27 & .4 & 0.4 & 2.2 & 24.3 & 62.8 & 10.2 & 2.1 \\
\hline Ry-3 & 2 & 0.3 & 4.1 & 0.4 & 60.2 & 2.29 & .4 & 0.4 & 1.8 & 22.3 & 60.2 & 11.8 & 2.1 \\
\hline Ry-4 & 2 & 0.4 & 4.9 & 0.4 & 59.1 & 2.32 & .4 & 0.4 & 2.1 & 23.9 & 59.1 & 10.7 & 2.1 \\
\hline 6 & 1.9 & 0.2 & 52.2 & 3.3 & 252 & 6.4 & 3.3 & 3.3 & 45 & 27.1 & 252 & 4.3 & 1.3 \\
\hline 7 & 1.9 & 0.2 & 47 & 3.1 & 245 & 6.1 & 3.1 & 3.1 & 40 & 25 & 245 & 4.2 & 1.2 \\
\hline 9 & 2 & 0.3 & 26 & 1.8 & 211 & 6 & 1.8 & 1.8 & & 25.1 & 211 & 3.2 & 0.8 \\
\hline 10 & 2.1 & 0.4 & 29 & 1.9 & 215 & 7 & 1.9 & 1.9 & & 26 & 215 & 3.5 & 0.9 \\
\hline 21 & 2.5 & 0.4 & 2.4 & 0.4 & 125 & 3.5 & .4 & 0.4 & & 26 & 125 & 5.8 & 2.3 \\
\hline 22 & 13.7 & 2.1 & 22.7 & 1.6 & 850 & 23 & 1.6 & 1.6 & & 114 & 850 & 8.4 & 2.4 \\
\hline 26 & 1.8 & 0.3 & 5 & 0.5 & 116 & 4 & .5 & 0.5 & & 13.3 & 116 & 8.4 & 2.1 \\
\hline 27 & 1.7 & 0.2 & 4.8 & 0.5 & 109 & 3 & .5 & 0.5 & & 13 & 109 & 8.2 & 2 \\
\hline 28 & 5.8 & 0.9 & 5 & 0.6 & 172 & 5 & .6 & 0.6 & & 54.8 & 172 & 11.6 & 2.4 \\
\hline 29 & 5.5 & 0.8 & 4.8 & 0.6 & 165 & 4.5 & .6 & 0.6 & & 51 & 165 & 11.3 & 2.4 \\
\hline 31 & 4.5 & 0.7 & 3 & 0.5 & 158 & 4.2 & .5 & 0.5 & & 49 & 158 & 11 & 2.3 \\
\hline 32 & 3.7 & 0.6 & 3 & 0.5 & 160 & 3.9 & .5 & 0.5 & & 47 & 160 & 11.1 & 2.3 \\
\hline 45 & 1.9 & 0.3 & 125 & 8.1 & 262 & 6 & 8.1 & 8.1 & & 21.1 & 262 & 9.7 & 3.7 \\
\hline KH-001 & 2.02 & 0.30 & 36.29 & 2.02 & 141.12 & 3.02 & 2.02 & 2.02 & 3.02 & 17.14 & 141.12 & 16.13 & 82.66 \\
\hline KH-008 & 2.06 & 0.21 & 39.22 & 2.06 & 144.48 & 2.06 & 2.06 & 2.06 & 4.13 & 20.64 & 144.48 & 3.10 & 5.16 \\
\hline KH-009 & 1.98 & 0.40 & 1.98 & 0.69 & 138.74 & 2.97 & .69 & 0.69 & 1.98 & 15.86 & 138.74 & 21.80 & 2.97 \\
\hline $\mathrm{KH}-010$ & 0.41 & 0.10 & 3.06 & 0.61 & 122.28 & 2.04 & .61 & 0.61 & 2.04 & 1.02 & 122.28 & 4.08 & 2.04 \\
\hline KH-011 & 0.43 & 0.11 & 2.13 & 0.21 & 117.37 & 2.13 & .21 & 0.21 & 2.13 & 2.13 & 117.37 & 4.27 & 1.07 \\
\hline KH-059 & 2.02 & 0.30 & 6.06 & 0.51 & 161.60 & 4.04 & .51 & 0.51 & 5.05 & 12.12 & 161.60 & 40.40 & 11.11 \\
\hline KH-071 & 1.97 & 0.20 & 3.94 & 0.30 & 118.08 & 2.95 & 30 & 0.30 & 2.95 & 8.86 & 118.08 & 17.71 & 2.95 \\
\hline KH-072 & 2.00 & 0.30 & 109.8 & 2.99 & 199.60 & 2.99 & 2.99 & 2.99 & 3.99 & 33.93 & 199.60 & 7.98 & 2.00 \\
\hline KH-096 & 0.50 & 0.10 & 0.50 & 0.10 & 139.30 & 0.90 & .10 & 0.10 & 1.00 & 2.99 & 139.30 & 3.98 & 1.00 \\
\hline KH-097 & 0.50 & 0.10 & 1.98 & 0.20 & 119.04 & 1.98 & .20 & 0.20 & 2.98 & 3.97 & 119.04 & 10.91 & 1.98 \\
\hline KH-098 & 1.96 & 0.10 & 1.96 & 0.29 & 147.15 & 1.96 & .29 & 0.29 & 3.92 & 6.87 & 147.15 & 12.75 & 1.96 \\
\hline KH-099 & 0.97 & 0.10 & 1.93 & 0.10 & 116.04 & 1.93 & .10 & 0.10 & 1.93 & 6.77 & 116.04 & 12.57 & 1.93 \\
\hline $\mathrm{KH}-100$ & 0.59 & 0.10 & 1.97 & 0.20 & 137.90 & 1.97 & .20 & 0.20 & 1.97 & 1.97 & 137.90 & 9.85 & 0.99 \\
\hline KH-101 & 3.02 & 0.20 & 45.27 & 0.91 & 140.84 & 2.01 & .91 & 0.91 & 3.02 & 130.8 & 140.84 & 4.02 & 1.01 \\
\hline KH-102 & 0.97 & 0.10 & 54.43 & 0.97 & 320.76 & 2.92 & .97 & 0.97 & 4.86 & 25.27 & 320.76 & 4.86 & 1.94 \\
\hline
\end{tabular}

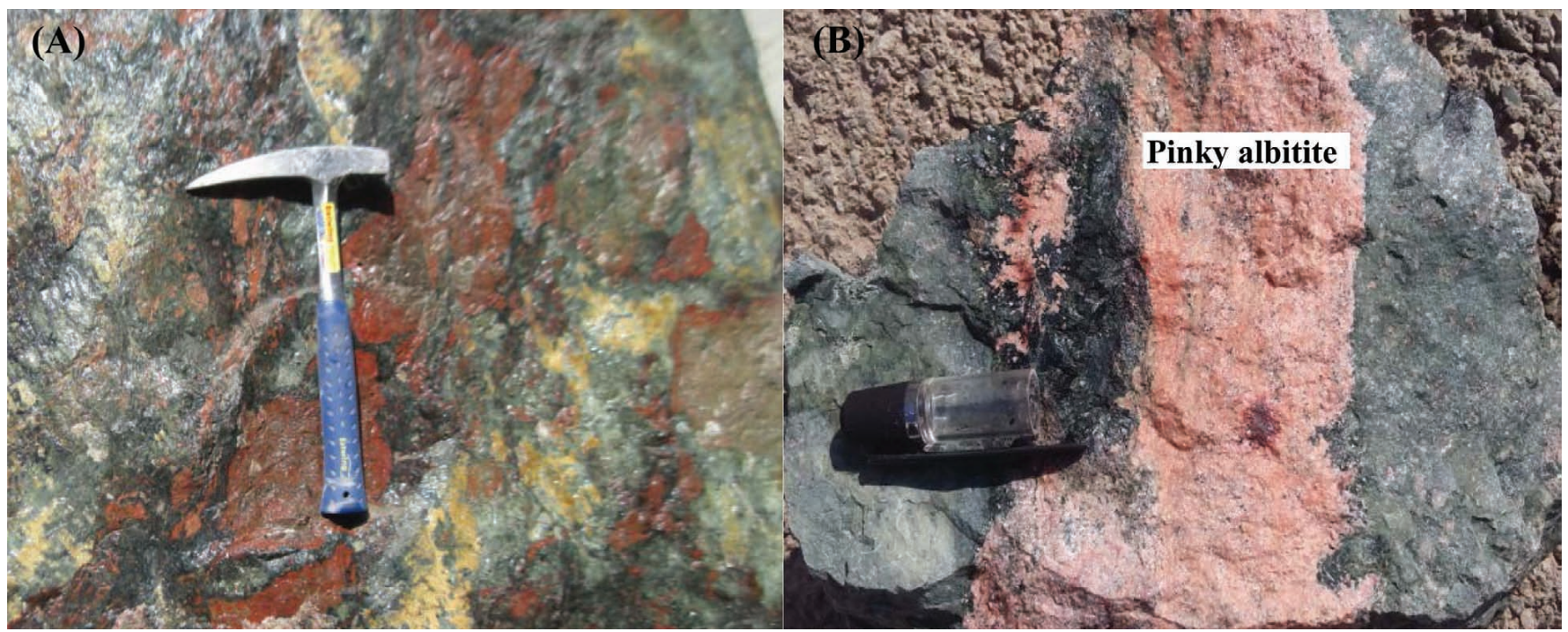

Figure 4. (A) Th-REE mineralization within hydrothermal breccia; (B) Hand specimen of pinkish albitite including Th-REE mineralization. 
zone (20 samples), volcanic host rock (10 samples) and diabase dykes (5 samples) at the Choghart deposit. The whole-rock concentrations of major oxides and trace elements were determined by inductively coupled plasma (ICP) optical emission spectroscopy (OES) and mass spectrometry (MS) at the Jaber-ebnehayyan laboratory of Nuclear Science and Technology Research Institute in Tehran, Iran. The detection limit for the main oxides and also the minor elements by ICP-OES is $<10 \mathrm{ppm}$, and for the trace elements by ICP-MS is $<0.1 \mathrm{ppm}$.

In addition, the data obtained from previous studies in the Bafq district were also used to strengthen the discussion of results obtained from the present study (Table 1; RAMEZANI \& TUCKER, 2003; MOHAMMAD TORAB, 2008; MIRZAEI BENI, 2014; RAJABI, et al., 2015). Petrographic and ore microscopic studies (including general recognition of mineral assemblages, alteration, metasomatic replacements and textures) were performed using an Olympus BX60 microscope at the petrography laboratory at the Shahid Beheshti University of Tehran. Based on optical microscope observations, 12 Th-REE mineralized thin-polished sections were selected for electron probe micro-analysis (EPMA). The detailed study of mineral assemblages, alteration, metasomatic replacements and textures was carried out at the mineralogy division of the Iranian Mineral Processing Research Centre (IMPRC) using a Cameca SX-100 electron mi- croprobe equipped with 5 wavelength-dispersive crystal spectrometers. Measurements were performed using an accelerating voltage of $15 \mathrm{kV}$, a beam current of $20 \mathrm{nA}$, beam size of $\sim 5 \mu \mathrm{m}$ and $15 \mathrm{~s}$ counting time for major elements and an accelerating voltage of $25 \mathrm{kV}$, a beam current of $20 \mathrm{nA}$, beam size of $\sim 3 \mu \mathrm{m}$ and 30 s counting time for trace elements. Natural oxides and silicates were used as standards and for calibration. Raw data were corrected for matrix effects with the ZAF correction procedure implemented by CAMECA.

\section{RESULTS AND DISCUSSION}

\subsection{Geochemistry of host rocks and mineralization}

The rare earth elements (REE), high-field-strength elements (HFSE), Th and transition elements are usually immobile during intense hydrothermal alterations. In addition, the hydrothermal fluids do not have a great capacity to transport some of the major elements such as Ti and P (e.g. ZHOU, 1999). In contrast, $\mathrm{Mg}, \mathrm{Ca}, \mathrm{Mg}, \mathrm{Na}, \mathrm{K}$, and some of the large ion lithophile elements (LILE; e.g. Sr, $\mathrm{Ba}$ and $\mathrm{Rb}$ ) are mobile under hydrothermal conditions (e.g., mobility SMITH \& SMITH, 1976). Immobile trace element geochemistry (including REE) is utilized here to deduce the tectonic setting of the igneous rocks.

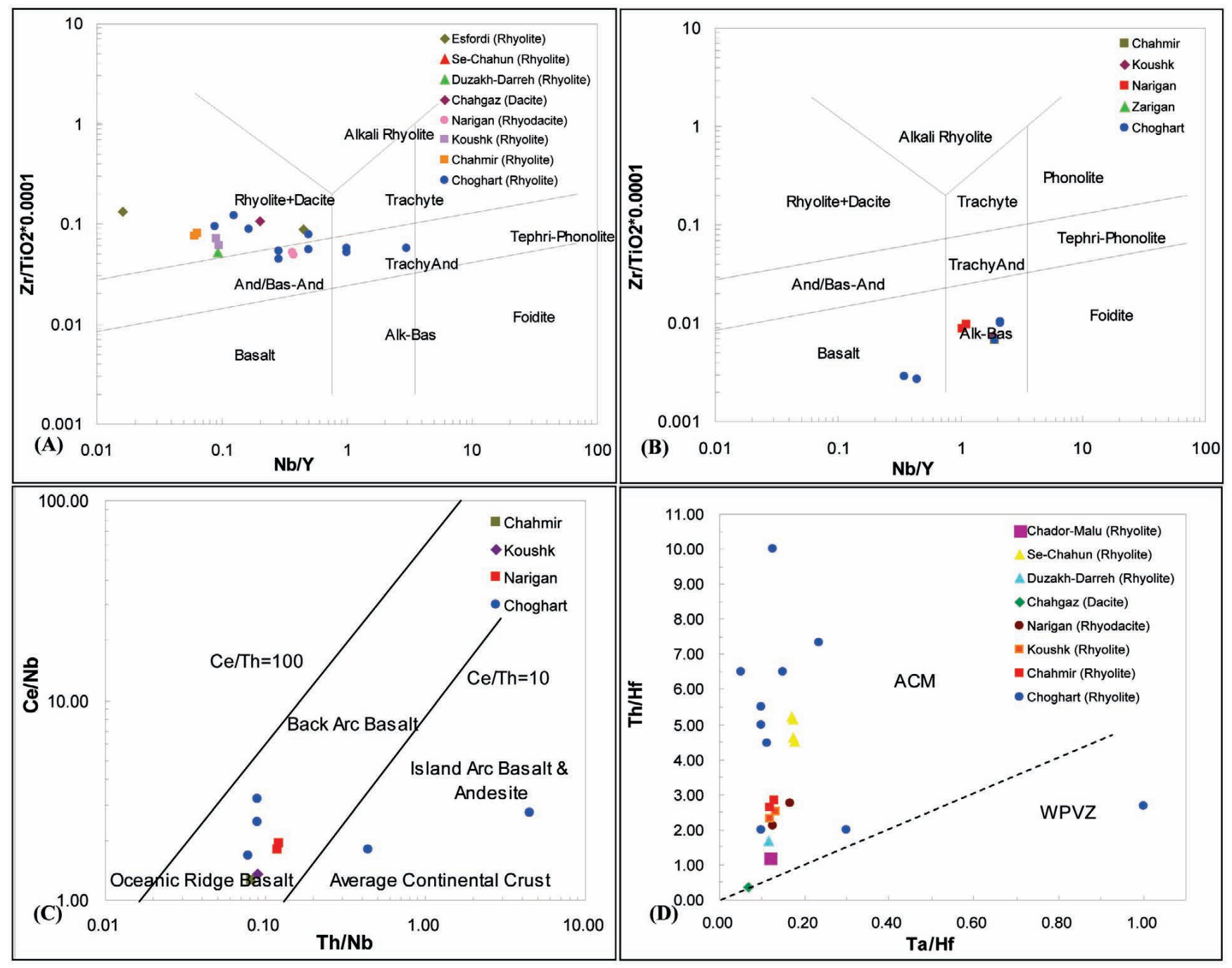

Figure 5. Log (Nb/Y) versus Log ( $\left.\mathrm{Zr} / \mathrm{TiO}_{2}\right)$ plot of WINCHESTER \& FLOYD (1977) (A) for pyroclastic and effusive rocks; (B) for diabase dykes of the Choghart- Bafq district; (C) Diagram of Th/Hf vs. Ta/Hf ratios for felsic rocks; (D) The Log (Ce/Nb) versus Log (Th/Nb) plot of SAUNDERS \& TARNEY (1991) for diabase rocks. 

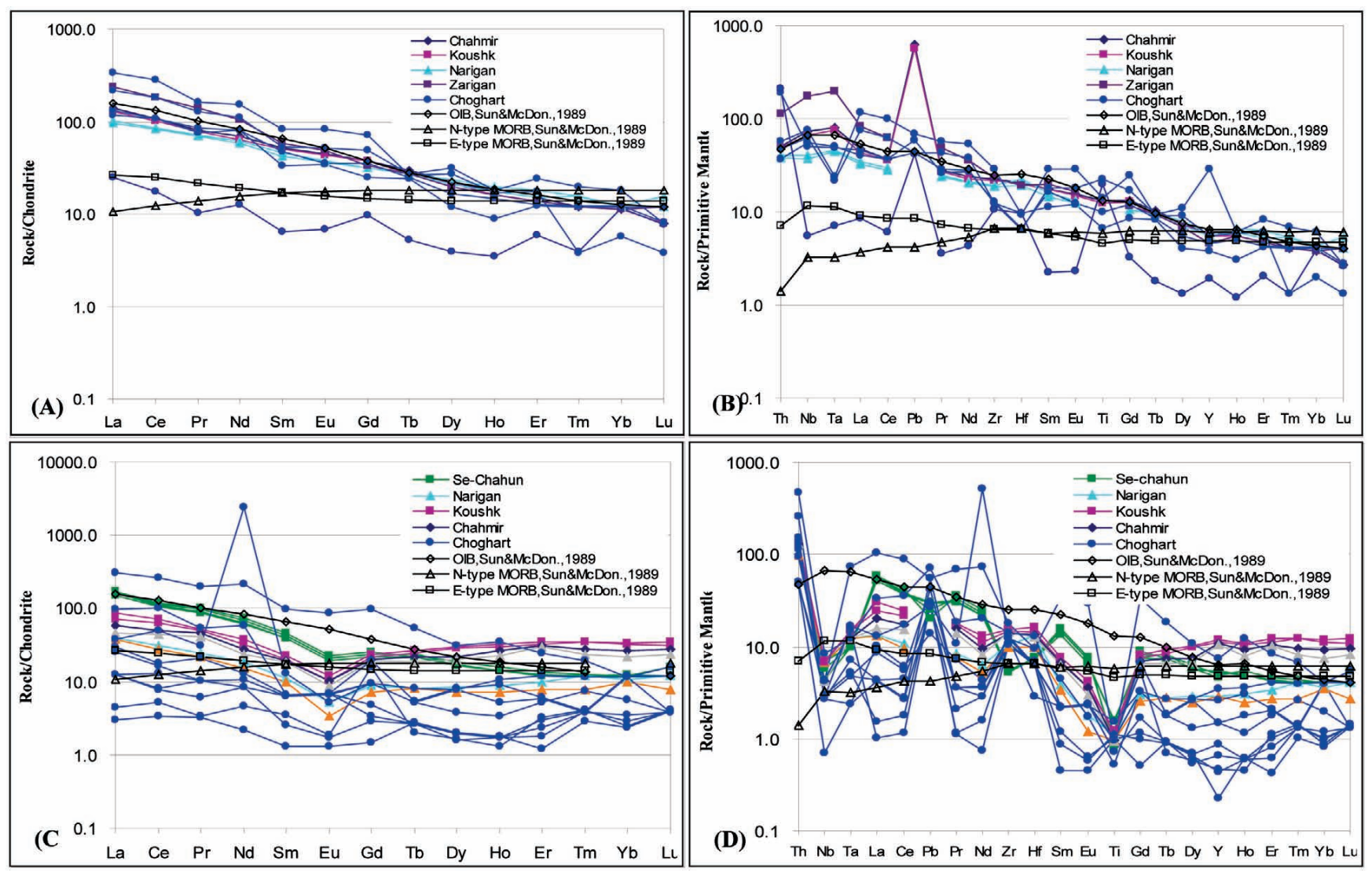

Figure 6. Chondrite and primitive mantle normalized rare earth elements and incompatible elements distribution patterns (Spider diagrams) (SUN and MC DONOUGH, 1989) for the Bafq district (A, B) diabase dykes and (C, D) rhyolitic rocks

Since the volcanic host rocks of the Choghart deposit are affected by hydrothermal alteration, the immobile elements are employed for petrogenetic interpretations of the rhyolites in the Bafq district (Chahmir, Koushk, se-Chahun, Choghart, etc.).

On the $\log \left(\mathrm{Zr} / \mathrm{TiO}_{2}\right)$ vs. $\log (\mathrm{Nb} / \mathrm{Y})$ plot of WINCHESTER \& FLOYD (1977), effusive rocks range from rhyolite to dacite in composition (two samples of Choghart lie within trachy-andesite field), and the samples of diabase dykes from the Bafq district plot within the alkaline basalt field (two samples of Choghart plot within the basalt field) (Figure 5a, b).

HFSE ratios in felsic volcanic rocks reflect the regional tectonomagmatic evolution. $\mathrm{Th} / \mathrm{Ta}, \mathrm{Th} / \mathrm{Hf}, \mathrm{Ta} / \mathrm{Hf}, \mathrm{Th} / \mathrm{Yb}$, and $\mathrm{Ta} / \mathrm{Yb}$ ratios help to define the tectonic setting of volcanism, separating oceanic arcs, active continental margins, and within-plate volcanic zones (SCHANDL \& GORTON, 2002). The rhyolites of the Bafq district particularly Choghart are enriched in Th and the light rare earth elements compared to $\mathrm{Ta}, \mathrm{Nb}$, and the heavy rare earth elements that are related to subduction zones. Variable $\mathrm{Th} /$ Ta ratios within individual deposits show fractionation trends (Figure 5c; SCHANDL \& GORTON, 2002).

$\mathrm{The} \mathrm{Ce} / \mathrm{Nb}$ vs. $\mathrm{Th} / \mathrm{Nb}$ plot of SAUNDERS \& TARNEY (1991) is useful in discriminating the tectonic environment of mafic rocks, because these elements are immobile during alteration processes. The diabase dyke samples of the Bafq district plot in the field of within-plate basalts (WPB); except for two samples of Choghart that plot out of this field in the field of continental margin volcanic arc basalt. This is possibly because of high concentrations of Th (Figure 5d). Furthermore, Th and Ta behave coherently in non-subduction-related basalts, decoupling only in the subduction environment (WOOD, 1980).
Figure 6. shows the Chondrite- and primitive-mantle-normalized REE patterns. The patterns for basaltic rocks (Figure 6a, b) display significant variation from LREE to HREE, similar to oceanic-island basalts (OIB). Most REE patterns of felsic rocks display enrichment in the LREE, with relatively flat HREE patterns (Figure 6c). Rhyolitic rocks of the Bafq district are noticeably enriched in Th and depleted in $\mathrm{Ta}, \mathrm{Nb}$ and $\mathrm{Ti}$ (Figure $6 \mathrm{~d}$ ). Because the mantle was progressively modified by subducted oceanic crust, felsic volcanic rocks became enriched in Th and LREE compared to $\mathrm{Ta}, \mathrm{Nb}$, and HREE (SCHANDL \& GORTON, 2002).

The Primitive-mantle-normalized geochemical patterns, arranged in order of incompatibly elements, indicate that the basaltic rocks of the Bafq district are more LREE- and HFSE (Th, Nb, $\mathrm{Ta}, \mathrm{Zr}, \mathrm{Hf}$ )-enriched rather than E-MORB or N-MORB (Figure $6 \mathrm{~d})$.

Considering the afore mentioned context, the Choghart rhyolite is similar to other felsic volcanic rocks and ECVSS granites formed in a continental margin setting, and like other continental margin rocks are noticeably enriched in Th and LREE compared to $\mathrm{Ta}, \mathrm{Nb}$, and the heavy rare earth elements. Likewise, the diabase dykes of Choghart have alkaline compositions similar to other diabase dykes and mafic rocks of the early Cambrian volcano-sedimentary sequence and were formed in a back-arc basin environment. Based on the results obtained during the study, the evolution of the Bafq district is genetically, related to the subduction of Palaeotethys oceanic crust beneath the Central Iranian microcontinent followed by formation of continental arc granitoids and rhyolites and then formation of back-arc basin diabase dykes (RAJABI et al., 2015). Diabase dykes were formed in a back-arc extensional setting after magnetite-apatite and Th-REE 


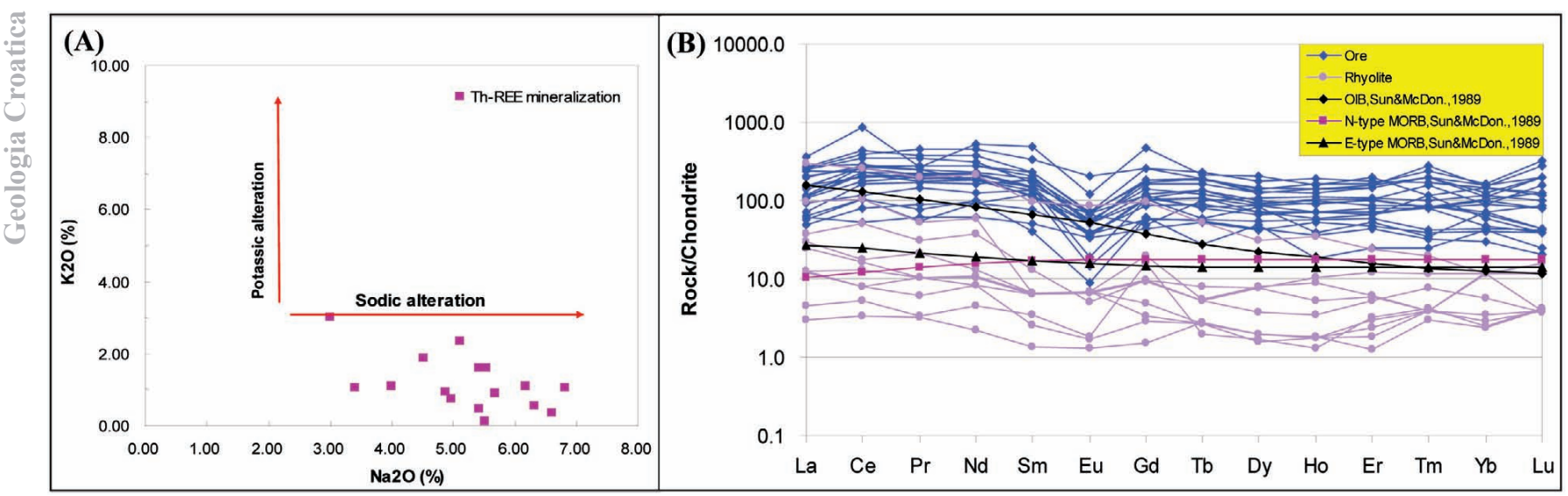

Figure 7. (A) The $\mathrm{K}_{2} \mathrm{O}$ vs. $\mathrm{Na}_{2} \mathrm{O}$ diagram for Th-REE mineralized samples; (B) Comparison of chondrite-normalized REE patterns of the Choghart rhyolite and the Th-REE mineralization zone.

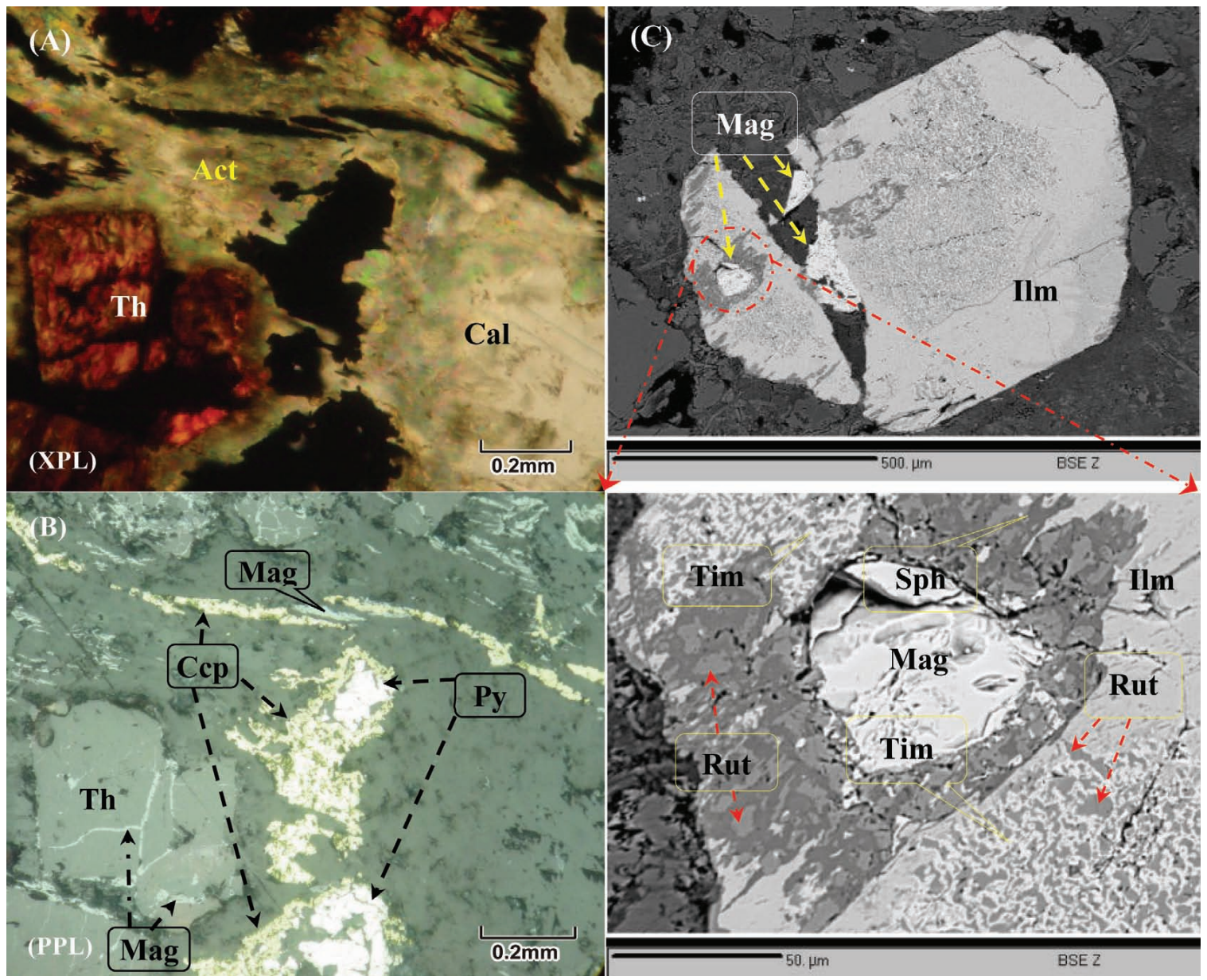

Figure 8. (A) Photomicrograph (transmitted-light) of thorite associated with actinolite and calcite; (B) Photomicrograph (reflected-light) of thorite accompanied by magnetite, pyrite and chalcopyrite; (C) BSE image; Conversion of ilmenite to sphene and rutile and also to rutile and titanomagnetite (Th: Thorite, Act: Actinolite, Ilm: Ilmenite, Ab: Albite, Py: Pyrite, Tim:Titanomagnetite, Ccp: Chalcopyrite, Cal: Calcite, Mag: Magnetite, Sph: Sphene, Rut: Rutile, Kfd: K-feldspar).

mineralization in the Choghart deposit. The $\mathrm{K}_{2} \mathrm{O}$ vs. $\mathrm{Na}_{2} \mathrm{O}$ diagram (Figure 7a) illustrates that all Th-REE mineralized samples lie within the high-Na field. This diagram indicates that in the Choghart Th-REE mineralization zone the sodic alteration occurred pervasively.

The Chondrite-normalized REE patterns (Fig. 7b) of Th-mineralization zone samples show a weak LREE/HREE fractionation and pronounced negative $\mathrm{Eu}$ anomaly. In addition, the similarity between the Chondrite-normalized REE patterns of the rhyolites and Th-mineralization zone in the Choghart mine is obvious. The negative Eu anomaly in the Th-mineralization zone of Choghart could be inherited from the fluid source. This implies that the fluid originated from rocks in which plagioclase has removed $\mathrm{Eu}^{2+}$ or equilibrated with them, because $\mathrm{Eu}^{2+}$ substitutes for $\mathrm{Ca}^{2+}$ in plagioclase, early crystallizing plagioclase in magma will remove $\mathrm{Eu}^{2+}$ from the system and thus a later exsolving fluid will be depleted in Eu. Additionally, if a fluid equilibrates with a plagioclase-bearing rock and doesn't dissolve pla- 

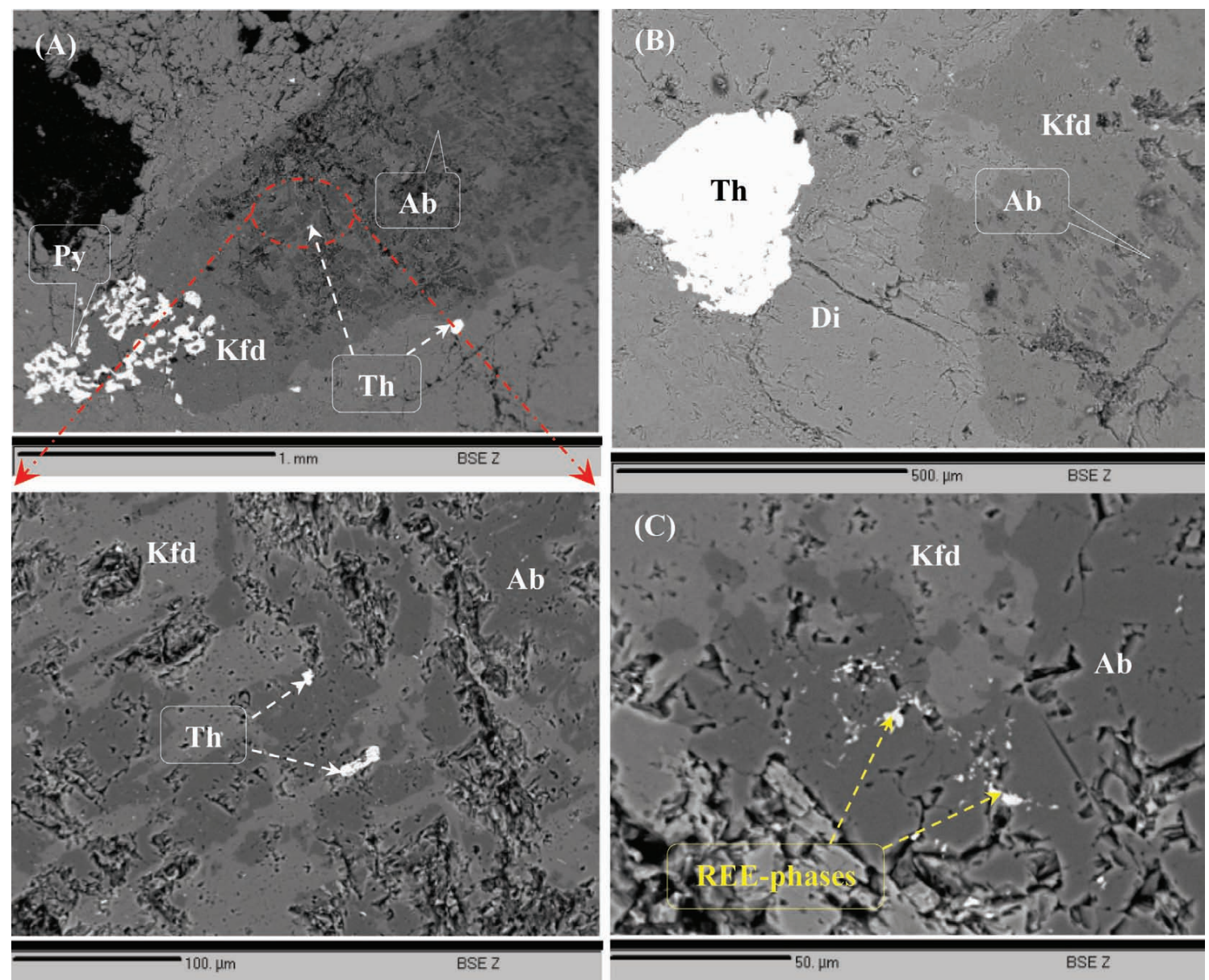

Figure 9. (A) BSE image; primary sphene as an individual crystal; (B) Photomicrograph (reflected-light) of the first generation of paragenetic galena with Th-REE mineralization; (C) BSE image; the second generation of galena formed after Th-REE mineralization as fracture filling of thorite (Th: Thorite, Ccp: Chalcopyrite, Mag: Magnetite, Sph: Sphene, Rut: Rutile, Aug: Augite, Gn: Galena).

gioclase, then the depletion in Eu will be inherited by the fluid. The negative Eu anomaly may reflect reducing conditions of the mineralizing fluid and depositional environment. Beside the REDOX conditions, the $\mathrm{Eu}^{2+} / \mathrm{Eu}^{3+}$ ratio can be controlled by temperature (BAU \& MÖLLER 1992). Since paragenetic magnetite, pyrite and chalcopyrite in mineral assemblages of the Th-mineralization zone were observed, the negative Eu anomaly is most likely due to the reducing conditions of the mineralizing fluid and depositional environment. According to Figure $7 \mathrm{~b}$, the chondritenormalized REE patterns of the Choghart rhyolite and Th-REE mineralization zone are similar, suggesting that Th and REE originated from continental margin Choghart rhyolitic magma.

\subsection{Mineralogy}

The microscope studies indicated that the main Th mineral in Th-REE mineralization zone is thorite (Figure 8a, b) which occurs in veinlets, either disseminated or as inclusions in other minerals such as albite and clinopyroxene. Minor amounts of thorite are associated with the sodic-calcic altered magnetite ore body. Sphene is the other host mineral of REE but is quantitatively less important than thorite. Two generations of sphene are recognized; the first, primary sphene which occurs as individual crystals and was likely precipitated directly from the mineralizing fluids (Figure 9a), and the second generation of sphene that formed by alteration of ilmenite (Figure 8c). Calcium- and silica-rich mineralizing fluids cause the alteration of ilmenite that is converted to sphene and rutile. Iron released from ilmenite alteration precipitated as magnetite (Figure $8 \mathrm{c}$ ). In some microscope sec- tions, ilmenite is observed to be converted to rutile and titanomagnetite (Figure 8c). Formation of magnetite, sphene and rutile suggests that probably the temperature of mineralizing fluids was relatively high. The occurrence of magnetite as a fracture filling in thorite indicates that it precipitated after thorite formation.

The silicate minerals accompanied by Th-REE mineralization include albite, amphibole and pyroxene. Following the nomenclature of LEAKE et al. (1997) and EPMA analyses (Table 2),

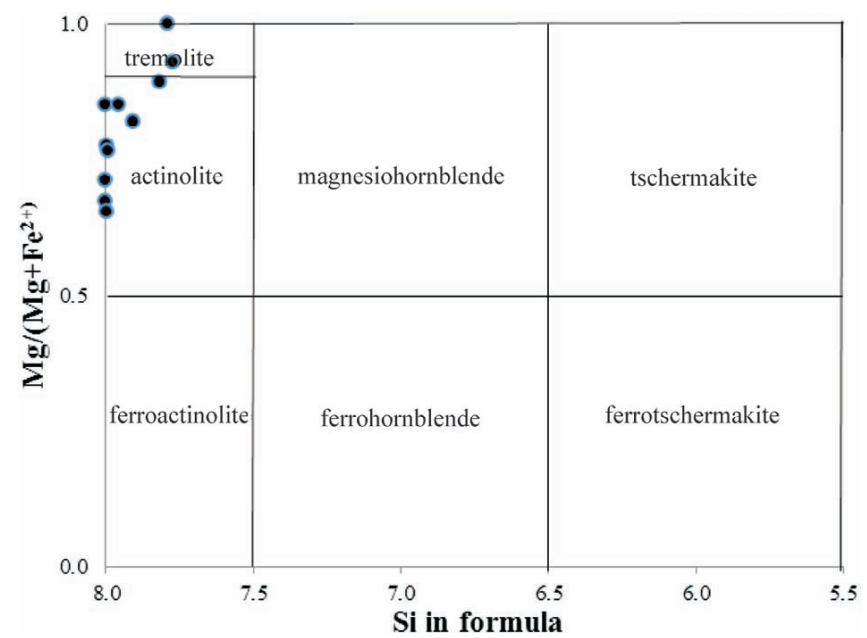

Figure 10. Classification of the calcic amphiboles in the Th-REE mineralization zone of Choghart. 
Table 2. Representative electron microprobe analyses of amphibole in some studied samples, Detection limit $<0.01 \%$.

\begin{tabular}{|c|c|c|c|c|c|c|c|c|c|c|c|c|c|}
\hline & AM1 & AM2 & AM3 & AM4 & AM5 & AM6 & AM7 & AM8 & AM9 & AM10 & AM11 & AM12 & AM13 \\
\hline $\mathrm{SiO}_{2}$ & 56.64 & 56.7 & 56.83 & 57.35 & 56.85 & 58.19 & 57.65 & 55.65 & 57.09 & 55.93 & 55.87 & 62.63 & 55.71 \\
\hline $\mathrm{TiO}_{2}$ & 0.06 & 0.06 & 0.00 & 0.02 & 0.03 & 0.04 & 0.03 & 0.00 & 0.04 & 0.18 & 0.15 & 0.03 & 0.03 \\
\hline $\mathrm{Al}_{2} \mathrm{O}_{3}$ & 0.46 & 1.08 & 0.47 & 0.42 & 0.57 & 0.66 & 1.41 & 0.77 & 0.75 & 0.47 & 0.48 & 0.26 & 0.38 \\
\hline $\mathrm{Fe}_{2} \mathrm{O}_{3}$ & 7.58 & 8.08 & 5.46 & 0.03 & 0.00 & 0.00 & 0.00 & 1.78 & 0.00 & 2.97 & 16.16 & 0.00 & 1.32 \\
\hline $\mathrm{FeO}$ & 10.84 & 9.89 & 11.79 & 9.45 & 9.65 & 6.14 & 6.09 & 17.70 & 11.54 & 13.00 & 0.00 & 5.77 & 12.62 \\
\hline $\mathrm{MnO}$ & 0.07 & 0.09 & 0.13 & 0.21 & 0.21 & 0.03 & 0.02 & 0.59 & 0.25 & 0.68 & 0.39 & 0.02 & 0.27 \\
\hline $\mathrm{CaO}$ & 11.61 & 11.5 & 11.64 & 12.86 & 13.12 & 13.5 & 13.45 & 8.69 & 12.90 & 10.66 & 8.28 & 0.08 & 11.69 \\
\hline $\mathrm{Na}_{2} \mathrm{O}$ & 0.19 & 0.19 & 0.24 & 0.27 & 0.2 & 0.00 & 0.05 & 2.43 & 0.17 & 1.02 & 0.39 & 0.03 & 0.08 \\
\hline $\mathrm{K}_{2} \mathrm{O}$ & 0.03 & 0.06 & 0.02 & 0.04 & 0.05 & 0.04 & 0.00 & 0.09 & 0.06 & 0.07 & 0.14 & 0.07 & 0.05 \\
\hline $\mathrm{H}_{2} \mathrm{O}^{*}$ & 2.17 & 2.19 & 2.16 & 2.15 & 2.13 & 2.17 & 2.17 & 2.05 & 2.13 & 2.10 & 2.15 & 2.24 & 2.07 \\
\hline Total & 101.5 & 101.68 & 101.32 & 101.06 & 100.48 & 100.28 & 100.45 & 100.38 & 101.0 & 100.88 & 100.25 & 98.9 & 98.9 \\
\hline \multicolumn{14}{|c|}{ Formulae based on 16 cations and 23 oxygens } \\
\hline Al & 0.075 & 0.174 & 0.125 & 0.069 & 0.086 & 0.108 & 0.189 & 0.132 & 0.124 & 0.079 & 0.000 & 0.041 & 0.065 \\
\hline $\mathrm{Ti}$ & 0.006 & 0.006 & 0.006 & 0.002 & 0.003 & 0.004 & 0.003 & 0.000 & 0.004 & 0.019 & 0.016 & 0.003 & 0.003 \\
\hline $\mathrm{Fe}^{3+}$ & 0.787 & 0.833 & 0.810 & 0.003 & & & & 0.195 & & 0.319 & 1.696 & & 0.144 \\
\hline $\mathrm{Mg}$ & 3.842 & 3.904 & 3.873 & 3.801 & 3.701 & 4.022 & 4.030 & 2.314 & 3.372 & 2.945 & 3.376 & 5.527 & 3.159 \\
\hline $\mathrm{Fe}^{2+}$ & 0.464 & 0.301 & 0.382 & 1.100 & 1.134 & 0.710 & 0.703 & 2.161 & 1.358 & 1.555 & 0.000 & 0.645 & 1.528 \\
\hline $\mathrm{Mn}$ & 0.008 & 0.010 & 0.009 & 0.025 & 0.025 & 0.004 & 0.002 & 0.073 & 0.030 & 0.082 & 0.046 & 0.002 & 0.033 \\
\hline $\mathrm{Ca}$ & 1.717 & 1.689 & 1.703 & 1.922 & 1.976 & 2.00 & 1.989 & 1.359 & 1.945 & 1.634 & 1.237 & 0.011 & 1.813 \\
\hline $\mathrm{Na}$ & 0.051 & 0.050 & 0.051 & 0.073 & 0.055 & 0.00 & 0.013 & 0.688 & 0.046 & 0.283 & 0.105 & 0.008 & 0.022 \\
\hline $\mathrm{K}$ & 0.005 & 0.010 & 0.008 & 0.007 & 0.009 & 0.007 & 0.00 & 0.017 & 0.011 & 0.013 & 0.025 & 0.012 & 0.009 \\
\hline $\mathrm{OH}^{*}$ & 2.00 & 2.00 & 2.00 & 2.00 & 2.00 & 2.00 & 2.00 & 2.00 & 2.00 & 2.00 & 2.00 & 2.00 & 2.00 \\
\hline Sum & 16.773 & 16.750 & 16.803 & 17.002 & 16.990 & 16.900 & 16.930 & 17.064 & 16.927 & 16.929 & 16.371 & 16.619 & 16.845 \\
\hline
\end{tabular}

Table 3. Representative electron microprobe analyses of pyroxene in some studied samples, Detection limit $<0.01 \%$.

\begin{tabular}{|c|c|c|c|c|c|c|c|c|c|c|c|c|c|c|c|}
\hline & PX1 & PX2 & PX3 & PX4 & PX5 & PX6 & PX7 & PX8 & PX9 & PX10 & PX11 & PX12 & PX13 & PX14 & PX15 \\
\hline $\mathrm{SiO}_{2}$ & 56.83 & 54.26 & 54.73 & 57.12 & 56.41 & 54.23 & 55.65 & 58.14 & 55.62 & 57.23 & 56.74 & 58.38 & 57.26 & 58.01 & 58.09 \\
\hline $\mathrm{TiO}_{2}$ & 0.00 & 0.13 & 0.13 & 0.00 & 0.02 & 0.05 & 0.00 & 0.01 & 0.13 & 0.02 & 0.04 & 0.17 & 0.21 & 0.29 & 0.24 \\
\hline $\mathrm{Al}_{2} \mathrm{O}_{3}$ & 0.47 & 0.3 & 0.36 & 0.24 & 0.15 & 0.2 & 0.77 & 0.66 & 0.39 & 0.27 & 0.52 & 1.05 & 1.01 & 1.16 & 1.09 \\
\hline $\mathrm{Fe}_{2} \mathrm{O}_{3}$ & 0.00 & 0.00 & 0.00 & 0.00 & 0.00 & 0.00 & 0.00 & 0.00 & 0.00 & 0.00 & 0.00 & 0.00 & 0.00 & 0.00 & 0.00 \\
\hline $\mathrm{Cr}_{2} \mathrm{O}_{3}$ & 0.00 & 0.00 & 0.00 & 0.00 & 0.01 & 0.00 & 0.00 & 0.00 & 0.01 & 0.02 & 0.00 & 0.00 & 0.00 & 0.00 & 0.00 \\
\hline $\mathrm{FeO}$ & 11.79 & 6.77 & 6.92 & 6.01 & 5.87 & 7.19 & 19.3 & 9.72 & 6.53 & 12.74 & 13.58 & 7.18 & 8.06 & 6.22 & 7.53 \\
\hline $\mathrm{MgO}$ & 17.5 & 14.48 & 14.69 & 15.27 & 15.1 & 13.97 & 10.63 & 18.06 & 15.91 & 16.08 & 14.43 & 20.6 & 19.59 & 21.82 & 20.43 \\
\hline $\mathrm{CaO}$ & 11.64 & 22.05 & 21.9 & 21.41 & 22.77 & 22.76 & 8.69 & 12.72 & 20.9 & 12.89 & 11.87 & 12.54 & 12.37 & 11.42 & 12.28 \\
\hline $\mathrm{Na}_{2} \mathrm{O}$ & 0.24 & 1.07 & 1.14 & 0.58 & 0.31 & 1.01 & 2.43 & 0.14 & 1.04 & 0.07 & 0.68 & 0.6 & 0.28 & 1.44 & 0.66 \\
\hline $\mathrm{K}_{2} \mathrm{O}$ & 0.02 & 0.02 & 0.00 & 0.00 & 0.00 & 0.01 & 0.09 & 0.03 & 0.00 & 0.00 & 0.06 & 0.17 & 0.19 & 0.36 & 0.18 \\
\hline Total & 98.62 & 99.18 & 100.0 & 100.8 & 100.8 & 99.53 & 98.15 & 99.79 & 100.7 & 99.6 & 99.52 & 100.8 & 99.05 & 100.8 & 100.6 \\
\hline \multicolumn{16}{|c|}{ Formulae based on 4 cations and 6 oxygens } \\
\hline $\mathrm{Ti}$ & 0.00 & 0.004 & 0.004 & 0.00 & 0.001 & 0.001 & 0.00 & 0.00 & 0.004 & 0.001 & 0.001 & 0.005 & 0.006 & 0.008 & 0.007 \\
\hline $\mathrm{Al}$ & 0.021 & 0.013 & 0.016 & 0.01 & 0.006 & 0.009 & 0.035 & 0.029 & 0.017 & 0.012 & 0.023 & 0.044 & 0.044 & 0.048 & 0.046 \\
\hline $\mathrm{Fe}^{3+}$ & 0.00 & 0.03 & 0.031 & 0.00 & 0.00 & 0.037 & 0.00 & 0.00 & 0.00 & 0.00 & 0.00 & 0.00 & 0.00 & 0.00 & 0.00 \\
\hline $\mathrm{Cr}^{3+}$ & 0.00 & 0.00 & 0.00 & 0.00 & 0.00 & 0.00 & 0.00 & 0.00 & 0.00 & 0.001 & 0.00 & 0.00 & 0.00 & 0.00 & 0.00 \\
\hline $\mathrm{Fe}^{2+}$ & 0.371 & 0.18 & 0.181 & 0.184 & 0.18 & 0.186 & 0.626 & 0.301 & 0.199 & 0.401 & 0.43 & 0.216 & 0.248 & 0.184 & 0.227 \\
\hline $\mathrm{Mn}$ & 0.004 & 0.003 & 0.004 & 0.004 & 0.003 & 0.003 & 0.019 & 0.01 & 0.004 & 0.009 & 0.051 & 0.004 & 0.002 & 0.002 & 0.003 \\
\hline $\mathrm{Mg}$ & 0.981 & 0.801 & 0.806 & 0.833 & 0.825 & 0.773 & 0.614 & 0.996 & 0.863 & 0.901 & 0.814 & 1.103 & 1.075 & 1.153 & 1.097 \\
\hline $\mathrm{Ca}$ & 0.469 & 0.877 & 0.863 & 0.839 & 0.894 & 0.905 & 0.361 & 0.504 & 0.815 & 0.519 & 0.481 & 0.483 & 0.488 & 0.434 & 0.474 \\
\hline $\mathrm{Na}$ & 0.017 & 0.077 & 0.081 & 0.041 & 0.022 & 0.073 & 0.183 & 0.01 & 0.073 & 0.005 & 0.050 & 0.042 & 0.02 & 0.099 & 0.046 \\
\hline $\mathrm{K}$ & 0.001 & 0.001 & 0.00 & 0.00 & 0.00 & 0.00 & 0.004 & 0.001 & 0.00 & 0.00 & 0.003 & 0.008 & 0.009 & 0.016 & 0.008 \\
\hline Sum & 4.00 & 4.00 & 4.00 & 4.00 & 4.00 & 4.00 & 4.00 & 4.00 & 4.00 & 4.00 & 4.00 & 4.00 & 4.00 & 4.00 & 4.00 \\
\hline
\end{tabular}

the amphibole belongs to the calcic group and is actinolite (except for 2 points which fall in the tremolite field, Figure 10). According to the nomenclature of MORIMOTO et al. (1989) and EPMA analyses (Table 3), all pyroxenes belong to Ca-rich pyroxene and fall mainly in the augite field and three samples have the composition of diopside (Figure 11). Also calcite, magnetite, pyrite, chalcopyrite and trace amounts of galena are associated with this type of mineralization. Two generations of galena are discernible; the first is contemporaneous with Th-REE mineralization (Figure 9b) and the second generation of galena formed after Th-REE mineraliza- 


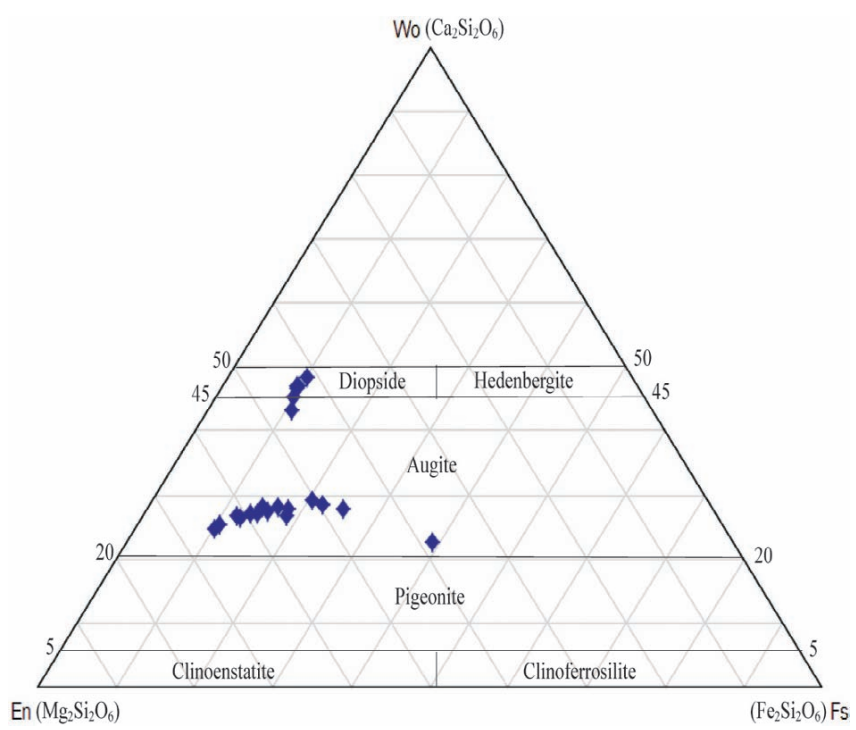

Figure 11. Classification of the Ca-rich pyroxene in the Th- REE mineralization zone of Choghart. tion as a fracture filling of thorite (Figure $9 \mathrm{c}$ ). $\mathrm{Pb}$ released from thorite (the decay product of $\mathrm{Th}$ ) probably forms the second generation of galena, provided the activity of $\mathrm{S}$ is sufficient. The presence of magnetite, pyrite and chalcopyrite is likely due to relatively reduced conditions in the thorite depositional environment. The paragenetic mineral assemblage of Th-REE mineralization of the Choghart iron oxide apatite deposit is shown in Figure 12.

The results of bulk chemical analyses show a high correlation of Ce, $\mathrm{La}, \mathrm{Y}$ and $\mathrm{Nd}$ concentrations with the Th content. The EMPA analyses show that thorite contains mean values of 9460 ppm Ce, 1950 ppm La, 1810 ppm Y and 110 ppm Nd (Table 4). The EMPA analyses of sphene shows mean of $8050 \mathrm{ppm}$ Ce, 3650 ppm Y while the contents of La and Y are below the detection limit (Table 5).

\subsection{Alkali Metasomatism}

Alkali metasomatism implies the transfer of the alkali ions, $\mathrm{Na}$ and $\mathrm{K}$, from a fluid phase, generated during the cooling of an igneous body, to the adjoining rocks. Albitite, microclinite, fenites, and the core zones of potassic alteration of porphyry systems are

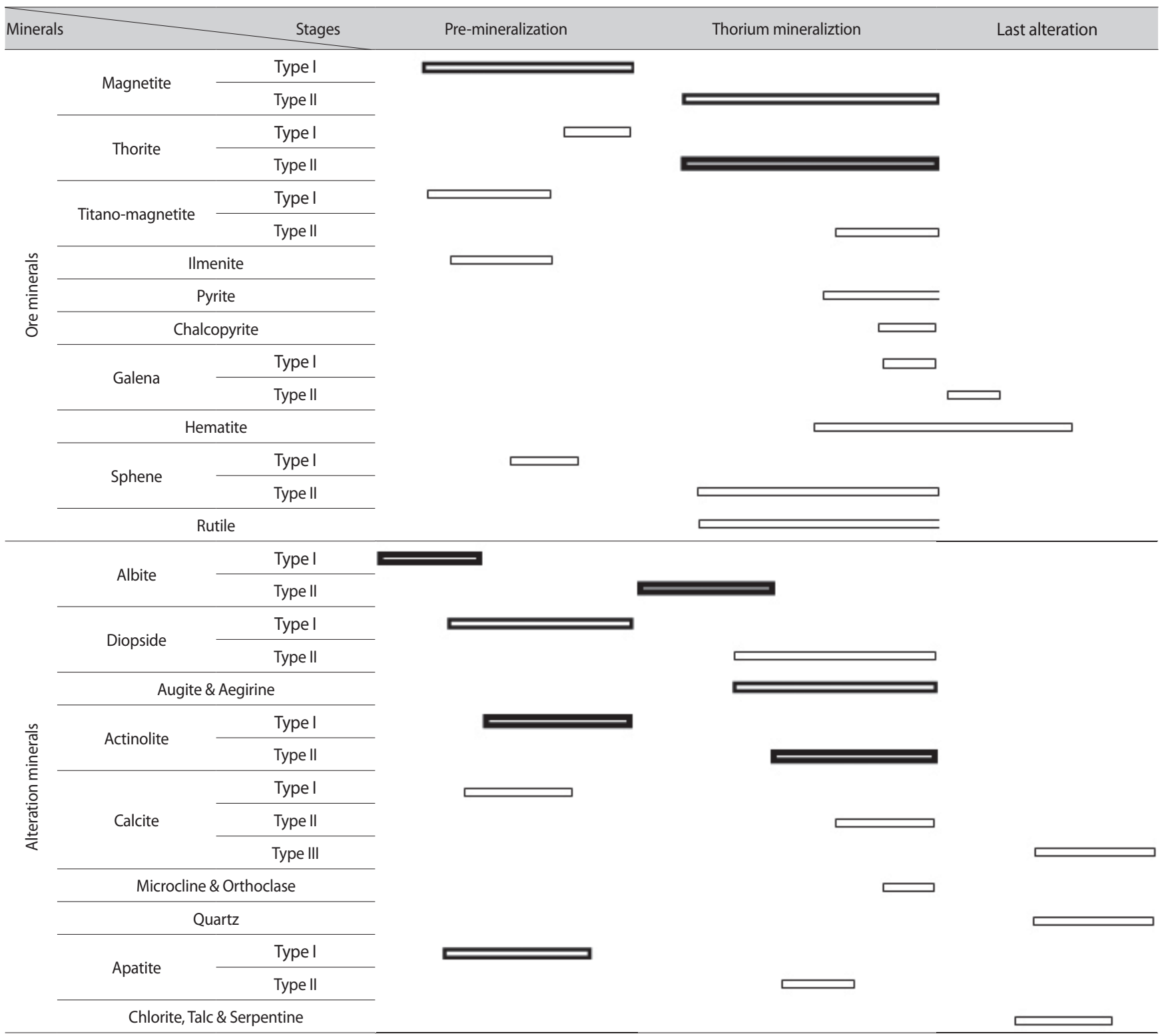

Figure 12. The paragenetic mineral assemblage of Th- REE mineralization of the Choghart deposit. 
Table 4. Electron microprobe analyses of thorite in some studied samples, Detection limit $<0.01 \%$.

\begin{tabular}{lcccccc}
\hline sample /element & $\mathrm{Y}$ & $\mathrm{La}$ & $\mathrm{Ce}$ & $\mathrm{Nd}$ & $\mathrm{P}$ & $\mathrm{Ca}$ \\
\hline Ch-001 & 0.35 & 0.01 & 0.92 & nd & 0.18 & 0.96 \\
Ch-001 & 0.17 & 0.04 & 0.96 & nd & 0.19 & 1.07 \\
Ch-002 & 0.26 & 0.1 & 0.91 & 0.49 & 0.13 & 0.88 \\
Ch-002 & 0.2 & 0.01 & 0.97 & 0.46 & 0.19 & 1.2 \\
Ch-003 & 0.36 & 0.07 & 0.94 & 0.18 & 0.13 & 1.16 \\
Ch-003 & 0.14 & nd & 0.91 & nd & 0.12 & 1.18 \\
Ch-004 & 0.22 & nd & 0.88 & 0.05 & 0.09 & 0.88 \\
Ch-004 & 0.1 & 0.02 & 0.91 & 0.69 & 0.07 & 1.23 \\
Ch-005 & 0.16 & 0.04 & 0.9 & 0.12 & 0.16 & 1 \\
Ch-005 & nd & nd & 1 & 0.01 & 0.15 & 0.24 \\
Ch-006 & 0.27 & 0.01 & 0.94 & nd & 0.16 & 1.01 \\
Ch-006 & nd & 0.03 & 0.98 & nd & 0.18 & 1.05 \\
Ch-007 & 0.1 & nd & 0.94 & nd & 0.14 & 0.98 \\
Ch-007 & nd & 0.04 & 0.93 & 0.02 & 0.17 & 1.12 \\
Ch-008 & 0.11 & nd & 1.03 & nd & 0.17 & 1.07 \\
Ch-008 & 0.03 & 0.01 & 1.01 & nd & 0.1 & 1.2 \\
Ch-009 & 0.54 & nd & 0.95 & 0.02 & 0.11 & 0.96 \\
Ch-009 & nd & nd & 1 & nd & 0.09 & 1.15 \\
Ch-010 & 0.37 & 0.01 & 0.93 & 0.1 & 0.09 & 1.01 \\
Ch-010 & 0.24 & nd & 0.91 & nd & 0.18 & 0.78 \\
\hline & & & & & &
\end{tabular}

commonly formed by alkali metasomatism. Also in some cases, perthitic textures in feldspar may indicate alkali metasomatism, rather than the separation during cooling of a two-phase assem-
Table 5. Electron microprobe analyses of sphene in some studied samples, Detection limit $<0.01 \%$.

\begin{tabular}{lccccccccc}
\hline Sample /element & $\mathrm{CaO}$ & $\mathrm{MnO}$ & $\mathrm{FeO}$ & $\mathrm{Al}_{2} \mathrm{O}_{3}$ & $\mathrm{SiO}_{2}$ & $\mathrm{TiO}_{2}$ & $\mathrm{P}_{2} \mathrm{O}_{5}$ & $\mathrm{Y}$ & $\mathrm{Ce}$ \\
\hline Ch-002 & 28.71 & nd & 1.26 & 0.74 & 30.36 & 35.04 & 0.03 & 0.23 & 1.08 \\
Ch-005 & 28.69 & 0.02 & 0.95 & 0.42 & 30.52 & 36.65 & 0.02 & 0.08 & 1 \\
Ch-007 & 28.93 & 0.03 & 1.37 & 0.11 & 30.55 & 36.35 & 0.03 & nd & 1.06 \\
Ch-008 & 28.55 & 0.01 & 1.36 & 0.62 & 30.35 & 36.83 & 0.01 & 0.15 & 1.08
\end{tabular}

Table 6. Electron microprobe analyses of Thorite in some studied samples for major oxides (in percent), Detection limit $<0.01 \%$.

\begin{tabular}{lcccccccc}
\hline sample /element & $\mathrm{MgO}$ & $\mathrm{CaO}$ & $\mathrm{MnO}$ & $\mathrm{FeO}$ & $\mathrm{Al}_{2} \mathrm{O}_{3}$ & $\mathrm{SiO}_{2}$ & $\mathrm{TiO}_{2}$ & $\mathrm{P}_{2} \mathrm{O}_{5}$ \\
\hline Ch-001 & 0.05 & 2.06 & 0.08 & 0.37 & 0.04 & 18.21 & 0.12 & 0.28 \\
Ch-002 & 0.1 & 2.14 & 0.14 & 0.52 & 0.05 & 19.04 & 0.11 & 0.16 \\
Ch-005 & nd & 2.35 & 0.08 & 0.35 & 0.05 & 18.11 & nd & 0.58 \\
Ch-006 & nd & 2.46 & 0.05 & 0.3 & 0.06 & 18.4 & nd & 0.45 \\
Ch-009 & 0.01 & 1.29 & 0.08 & 0.47 & 0.06 & 19.19 & 0.01 & 0.6 \\
Ch-010 & nd & 1.3 & 0.1 & 0.43 & 0.02 & 18.32 & 0.04 & 0.43
\end{tabular}

blage (PIRAJNO, 2013). Perthite formation in the Choghart Th-REE mineralization zone clearly shows alkali metasomatism (Figure 13a).

The replacement of $\mathrm{K}$ by Na in feldspars, probably by ion exchange, is shown by the presence of albite inclusions in the $\mathrm{K}$-feldspar host. These inclusions can occur either as veinlets or irregular shapes, and do not follow crystallographic directions, as would be the case for melt-fluid unmixing (PIRAJNO, 2013).
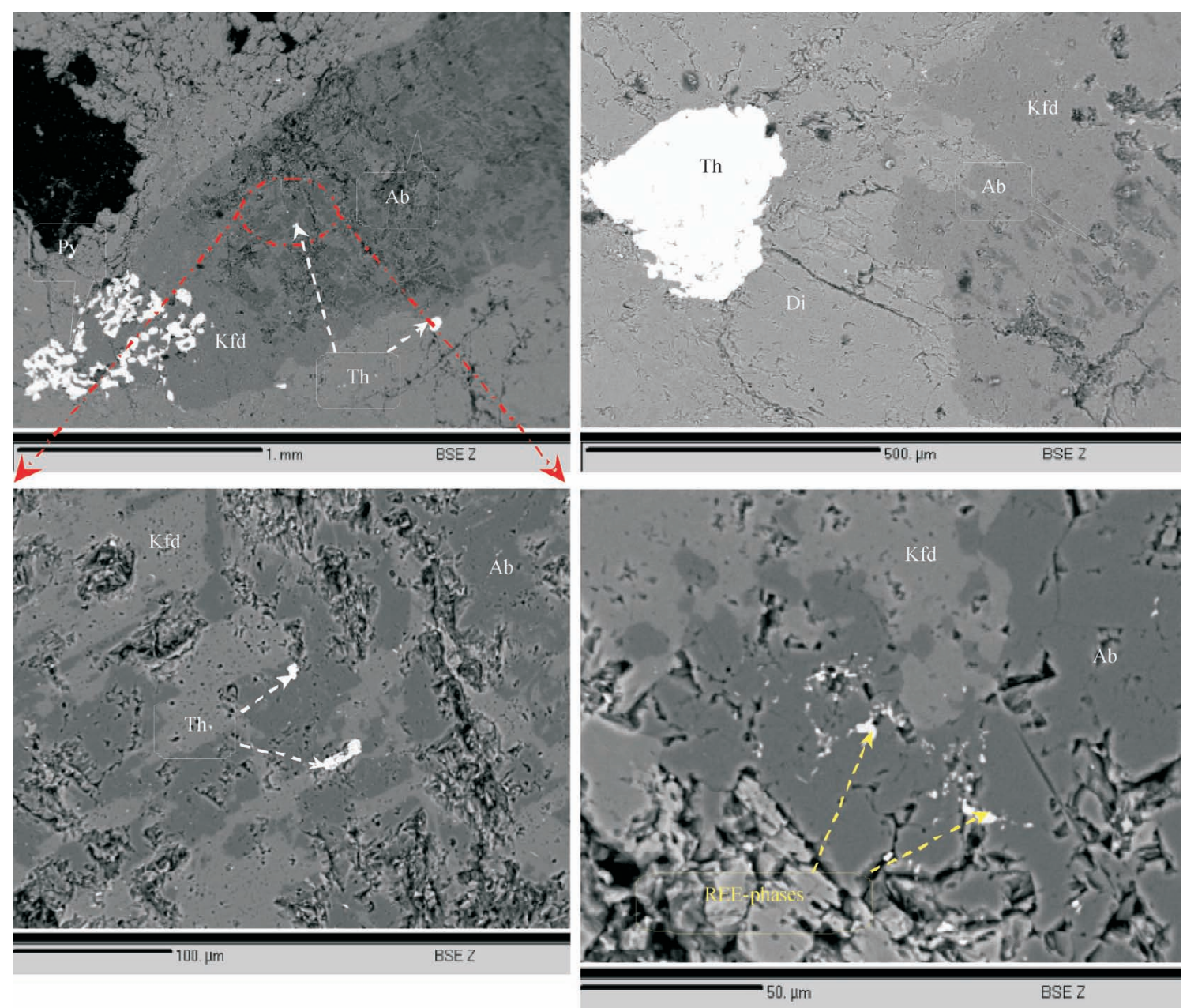

Figure 13. (A) BSE image; Perthite formation due to alkali metasomatism; (B) BSE image; Formation of albite inclusions in K-feldspar due to alkali metasomatism; (C) BSE image; Replacement of K-feldspar by albite (Th:Thorite, Ab: Albite, Py: Pyrite, Di: Diopside, Kfd: k-feldspar). 
This event is clearly associated with Th-REE mineralization at Choghart (Figure 13b).

The replacement of alkali feldspar by albite (albitization or Na-feldspathization) shows the more common form of sodic metasomatism. This replacement may proceed from either preexisting perthites, or direct replacement of K-feldspar with late formed albites (POLLARD, 1983).

The replacement of K-feldspar by albite occurs pervasively accompanied with the Th-REE mineralization zone at Choghart (Figure 13c, 4b). Albitization of K-feldspar can be written as follows:

$$
\mathrm{KAlSi}_{3} \mathrm{O}_{8}+\mathrm{Na}^{+}=\mathrm{NaAlSi}_{3} \mathrm{O}_{8}+\mathrm{K}^{+}
$$

The development of albite-rich rocks (albitites) is typically accompanied by rare element mineralization $(\mathrm{Nb}, \mathrm{Ta}, \mathrm{Sn}, \mathrm{W}, \mathrm{Li}$, $\mathrm{Be}$ ). Sodium-enrichment is associated with elevated concentrations of Fe, U, Th, Zr, Nb, Sn, Zn, and HREE. Na-metasomatised rocks are also more prone to be enriched in $\mathrm{Rb}, \mathrm{Th}, \mathrm{Nb}, \mathrm{La}, \mathrm{Ce}$, $\mathrm{Hf}, \mathrm{Zr}$, and $\mathrm{Y}$ with regard to K-metasomatised rocks (KINNAIRD, 1985). The Choghart Th-REE mineralization zone is enriched in Th, La, Ce, Nd, and Y.

The high-temperature post-magmatic processes can promote the mobilization and concentration of thorium. In these processes thorium is usually associated with rare-earth elements (the lanthanides). Most post-magmatic thorium-containing deposits are connected with pneumatic-hydrothermal or high-temperature hydrothermal processes. At present we know that Th-REE deposits have post-magmatic genesis (TITAYEVA, 1994).

Most high-temperature Th-REE deposits (of pneumato-hydrothermal genesis) were formed as a result of the metasomatic replacement of country rocks. They are characterized by early albitization, K-feldspathization, aegirinization, amphibolitization, and the formation of skarn. Ore minerals are niobates, tantalo- and titano-niobates (euxenite, pyrochlore, priorite, fergusonite, and others), and the silicates of the rare earths, thorium, and zirconium. High-temperature hydrothermal deposits are characterized by metasomatic replacements, associated with amphibolitization, aegirinization, biotitization, greisenization, and filled open cavities. Niobates, titano- and tantalo-niobates are represented here in small quantities. Rare-earth phosphates (monazite and xenotime) dominate with some rare-earth silicates (orthite, cerite, britholite, etc.). The medium- and low-temperature deposits are usually veined with a characteristic change in country rocks (feldspathization, carbonatization, and silicification). Ore minerals are represented by haematite, carbonates and fluorocarbonates of the rare earths (bastnaesite, parisite, synchysite, etc.), and the sulfides of $\mathrm{Fe}, \mathrm{Cu}, \mathrm{Pb}$, and $\mathrm{Zn}$ (TITAYEVA, 1994).

The main paragenetic associations of thorium are the lanthanides. In high-temperature deposits Th is usually associated with $\mathrm{Ta}, \mathrm{Nb}, \mathrm{Ti}$, and occasionally with Mo, W, Sn, Be. In moderatetemperature deposits $\mathrm{Th}$ is paragenetically associated with $\mathrm{Pb}$, $\mathrm{Zn}, \mathrm{Cu}$. The anion components such as $\mathrm{Cl}^{-}, \mathrm{HCO}_{3}{ }^{-}, \mathrm{CO}_{3}{ }^{2-}, \mathrm{HS}^{-}$, $\mathrm{S}^{2-}$ and $\mathrm{F}^{-}$are important and control the mobility of metals in post-magmatic fluids (TITAYEVA, 1994).

As mentioned above the Th-REE mineralization zone (thorite and sphene) in Choghart is associated with albitization, amphibolitization (actinolite), pyroxenitization (augite and diopside), carbonatization and minor K-feldespatization (microcline), as well as the occurrence of pyrite and minor amounts of chalcopyrite, considered to be a moderate-temperature post-magmatic ThREE mineralization type.

\subsection{Mineral formation conditions}

Thermodynamic calculations have indicated that fluoride or mixed carbonate-fluoride complexes can dominate REE speciation (e.g., WOOD, 1990a, b). The scarcity of the F-bearing REE minerals (flourapatite) in the Th-REE mineralized zone of Choghart, however, implies that a high concentration of fluorine was probably, only locally, achieved and is not necessarily a component of the composite ore-forming fluids.

The presence of calcite along with calcic- amphibole and pyroxene (actinolite and augite, respectively), the high content of $\mathrm{Ca}$ in thorite (Table 6; up to $2.3 \% \mathrm{CaO}$ ) and the occurrence of sphene in the Choghart Th-REE mineralization zone imply that thorite crystallized from a $\mathrm{Ca}^{2+}$ - and $\mathrm{CO}_{3}{ }^{2-}$ - bearing aqueous solution under conditions of low activity of $\mathrm{F}^{-}$.

Considering that dolomitic xenolites of the Esfordi formation are observed in the volcanic host rocks of the Choghart deposit, the portion of $\mathrm{CO}_{2}$ in the mineralizing fluids is supplied by digestion of these xenolites.

In postmagmatic mineralization, thorium migrates in alkaline solutions, particularly in the form of complex carbonate compounds with the formula $\mathrm{Th}\left(\mathrm{CO}_{3}\right)_{\mathrm{n}}{ }^{-(2 \mathrm{n}-4)}$ (TITAYEVA, 1994).

According to the presence of paragenetic calcite accompanied with thorite and sphene in Th-REE mineralization, Th and REE transport was likely because of the presence of the carbonate complexes in mineralizing fluids.

According to TITAYEVA (1994) and PIRAJNO (2009) at the end of albitization processes, the thorium and uranium concentrations increase. Part of REE and U-Th is retained in microfissures filled with haematite and chlorite. The reddish colour is attributed to the presence of micro-haematite in micro-fractures. Although, WILDE (2013) has portrayed that the red or pink coloration is owing to the presence of fine-grained disseminated haematite or hydrothermal apatite. Our data revealed that albites from the Choghart Th-REE mineralization zone contain K-feldspar and minor Th silicate mineral inclusions (i.e. thorite) that give albite a more reddish colour (Figure 4B).

\section{CONCLUSIONS}

MOORE \& MODABBERI (2003) suggest that the separation of an iron oxide melt and the following hydrothermal processes dominated by alkali metasomatism have both been involved to in different degrees in the formation of the Choghart deposit. Alternatively, the Choghart rhyolite is enriched in Th and LREE similar to other continental margin felsic volcanic rocks. Chondritenormalized REE patterns of the Choghart rhyolite are similar to the Th-REE mineralization zone, indicating that Th and REE originated from a continental margin Choghart rhyolitic magma.

We suggest that in the Early Cambrian (about $533 \mathrm{Ma}$ ) calcalkaline granitoid magmatism associated with a subduction zone in the Choghart deposit initially formed a magnetite-apatite ore body and sodic-calcic alteration followed by penetration of the remaining magmatic fluids into the rhyolitic host rocks and also sodic-calcic alteration related to iron mineralization and partially brecciation. These fluids maintain elevated concentrations of metals such as Fe, Th and REE that were originally scavenged from the rhyolitic silicate melt due to the magmatic temperatures and high salinity of the fluid (REED et al., 2000; SIMON et al., 2004, 2005, 2006; ZAJACZ et al., 2012; FRANK et al., 2011; MIGDISOV et al., 2014; HURTING \& WILLIAMS-JONES, 2014). These fluids caused sodic metasomatism (albitization), carbonatization, actinolitization and pyroxenitization, minor K-feld- 
spatization (microcline) as well as generation of the minerals such as thorite and sphene. Alternatively, the Th-REE mineralization zone may have formed from entirely different fluids related to a later intrusion such as the resurgent central plutons.

The high $\mathrm{CO}_{2}$ content of the fluid facilitates formation of metal-carbonate complexes. The presence of paragenetic calcite with thorite suggests that carbonate complexes most likely transferred the Th and REE. Considering that dolomitic xenoliths of the Esfordi Formation are observed in the volcanic host rocks of the Choghart deposit, the portion of $\mathrm{CO}_{2}$ in the mineralizing fluids is supplied by digestion of these xenoliths. The negative $\mathrm{Eu}$ anomaly from the Th-REE mineralization zone and the presence of paragenetic magnetite, pyrite and chalcopyrite with thorite suggests relatively reduced conditions in the Th-REE mineralization environment.

\section{ACKNOWLEDGEMENT}

This paper is based partly on the main author's $\mathrm{PhD}$ thesis at Shahid Beheshti University of Tehran, Iran. This research was also supported by the Nuclear Science and Technology Research Institute of AEOI and Shahid Beheshti University research centre.

\section{REFERENCES}

AGHANABATI, A. (1998): Major sedimentary and structural units of Iran (map).- Int. Geosci., 7, 29-30.

AGHANABATI, A. (2008): Stratigraphy Encyclopedia of Iran - Precambrian to Silurian.- Geological Survey Survey and Mineral Exploration of Iran. Tehran, $658 \mathrm{p}$.

ALAVI, M. (1991): Tectonic map of the Middle East (scale 1:5.000.000).- Geological Survey and Mineral Exploration of Iran, Tehran.

BAGHERI, S. \& STAMPFLI, G.M. (2008): The Anarak, Jandaq and Posht-e-Badam metamorphic complexes in Central Iran: new geological data, relationships and tectonic implications.- Tectp., 451, 123-155. doi: 10.1016/j.tecto.2007.11.047

BAU, M. \& MÖLLER, P. (1992): Rare earth element fractionation in metamorphogenic hydrothermal calcite, magnesite and siderite.- Mineral. and Petrol., 45, 231-246. doi: 10.1007/BF01163114

CUNEY, M., EMETZ, A., MERCADIER, J. \& MYKCHAYLOV, V. (2012): Uranium deposits associated with Na-metasomatism from central Ukraine: A review of some of the major deposits and genetic constraints.- Ore Geol. Rev., 44, 82-106. doi: 10.1016/j.oregeorev.2011.09.007

DAHLKAMP, F.J. (1993): Uranium Ore Deposits.- Springer-Verlag, Berlin, 460 p. doi: 10.1007/978-3-662-02892-6

DAHLKAMP, F.J. (2009): Uranium Deposits of the world - Asia.- Springer-Verlag, Berlin, 493 p.

DALIRAN, F. (2002): Kiruna-type iron oxide-apatite ores and 'apatites' of the Bafq district, Iran, with an emphasis on the REE geochemistry of their apatites.- In: PORTER, T. M. (ed.): Hydrothermal Iron Oxide Copper Gold and Related Deposits: A Global Perspective., 2. PGC Publishing, Adelaide, Australia, 303-320.

DALIRAN, F., STOSCH H.G. \& WILLIAMS, P.A. (2009): Review of the Early Cambrian Magmatic and Metasomatic events and their bearing on the genesis of the $\mathrm{Fe}$ oxide-REE-apatite deposits (IOA) of the Bafq District, Iran.- In: WILLIAMS et al. (eds.): Smart Science for Exploration and Mining, Proceedings of the 10th Biennial SGA Meeting, Townsville, Australia 17th-20th August.

DEHGHAN, A.R. (2011): Geological prospecting plan of the Choghart deposit, 1:4200, Report of Central Iron Ore Company (In Persian)

FELDMAN, G.K. (1926): About some varieties of spherulite quartz of the ZhovtaRichka mine.- Dnipropetrovsk: Bull. Geol. Mining circle of Dnipropetrovsk Mining Institute, 2.

FORSTER, H. \& JAFARZADEH, A. (1994): The Bafq mining district in central Iran a highly mineralized infracambrian volcanic field.- Econ. Geol., 89, 1697-1721. doi: 10.2113/gsecongeo.89.8.1697

FRANK, M.R., SIMON, A., PETTKE, T., CANDELA, P. \& PICCOLI, P. (2011): Gold and copper partitioning in magmatic-hydrothermal systems at $800^{\circ} \mathrm{C}$ and 100 MPa.- Geochim. Cosmochim Acta, 75/9, 2470-2482.

HAGHIPOUR, A. (1977): Geological map of the Biabanak-Bafq area-- Geological Survey of Iran, scale 1:500.000

HAGHIPOUR, A. \& PELISSIER, G. (1968): Geology of the Posht-e-Badam-Saghand area (east central Iran).- Iran Geological Survey Note, 48, 144 p.

HUCKRIEDE, R., KURSTEN, M. \& VENZLAFF, H. (1962): The geology of the area between Kerman and Saghand (Iran). Beih.- Geol. Jb., 53, 197 p.
HURTING, N.C. \& WILLIAMS-JONES, A.E. (2014): An experimental study of the transport of gold through hydration of $\mathrm{AuCl}$ in aqueous vapour and vapour-like fluids.- Geochim. Cosmochim. Acta, 127, 305-325.

IAEA (2014): Uranium 2014.- Resources, production and demand, 504 p.

KARGARANBAFGHI, F., NEUBAUER, F., GENSER, J., FAGHIH, A. \& KUSKY, T (2012): Mesozoic to Eocene ductile deformation of western Central Iran: From Cimmerian.- Tectp., 564-565, 83-100.

KINNAIRD, J.A.(1985): Hydrothermal alteration and mineralization of the alkaline anorogenic ring complexes of Nigeria.- African Earth Sci., 3, 229-252. doi: 10.1016/0899-5362(85)90038-7

LEAKE, B.E., WOOLEY, A.R., ARPS C.E.S., BIRCH, W.D., GILBERT, M.C., GRICE, J.D., HAWTHORNE, F.C., KATO, A., KISCH, H.J., KRIVOVICHEV, V.G., LINTHOUT, K., LAIRD, J., MANDARINO, J.A., MARESCH W.V., NICKEL, E.H., ROCK, N. M.S., SCHUMACHER, J.C., SMITH, D.C., STEPHENSON, N.C.N., UNGARETTI, L., WHITTAKER, E.J.W. \& YOUZHI, G. (1997). Nomenclature of amphiboles: Report of the subcommittee on amphiboles of the International Mineralogical Association, Commission on new minerals and mineral names.-Am. Mineral., 82, 1019-1037.

MIGDISOV, A.A., BYCHKOV, A.Y., WILLIAMS-JONES, A.E. \& VAN-HINSBERG, V.J. (2014): A predictive model for the transport of copper by HCl-bearing water vapour in ore-forming magmatic-hydrothermal systems: Implications for copper porphyry ore formation.- Geochim. Cosmochim. Acta, 129, 33-53. doi: 10.1016/j. gca.2013.12.024

MIRZAEI BENI, Z., EMAMI, M.H., SHEIKHZAKARIAEE, S.J. \& NASR ESFAHANI, A. (2014): Petrography of plutonic rocks in the Late Cambrian (Rizu Series), Sechahun Iron oxide deposit, Bafq mining district, Central Iran.- Biodiversity and Environmental Sciences (JBES), 5/4, 610-616.

MOHAMMAD TORAB, F. (2008): Geochemistry and metallogeny of magnettite-apatite deposits of the Bafq mining district, central Iran.- Ph.D Thesis, Faculty of Energy and Economic Sciences, Technical university of Claustal, $131 \mathrm{p}$.

MOORE, F. \& MODABBERI, S. (2003): Origin of Choghart iron oxide deposit, Bafq mining district, Central Iran: new isotopic and geochemical evidence.- Journal of Sciences Islamic Republic of Iran, 14/3, 259-270.

MORIMOTO, N., FABRIES, J., FERGUSON, A.K., GINZBURG, I.V., ROSS, M., SEIFERT, F.A. \& ZUSSMAN, J. (1988): Nomenclature of Pyroxenes.-Am. Mineral., 73, 1123-1133.

NADIMI, A. (2007): Evolution of the Central Iranian basement.- Int. Gondwana Res., 12, 324-333. doi: 10.1016/j.gr.2006.10.012

PIRAJNO, F. (2009): Hydrothermal Processes and Mineral Systems.- Springer, 1250 p. doi: $10.1007 / 978-1-4020-8613-7$

PIRAJNO, F. (2013): Effects of metasomatism on mineral systems and their host rocks: alkali metasomatism, skarns, greisens, tourmalinites, rodingites, black-wall alteration and listvenites.- In: HARLOV, DE. \& AUSTRHEIM, H. (eds.): Metasomatism and metamorphism: the role of fluids in crustal and upper mantle processes. Lecture Series in Earth Science, Springer, 203-251. doi: 10.1007/978-3-64228394-9_7

POLLARD, PJ. (1983): Magmatic and post-magmatic processes in the formation of rocks associated with rare element deposits.- Trans. Inst. Min. Metall., 92, B1-B9.

RAJABI, A. (2008): Geology, mineralogy, texture and structure, geochemistry and genesis of Chahmir $\mathrm{Zn}-\mathrm{Pb}$ deposit, south of Behabad, Yazd Province.- M.Sc. Thesis, Faculty of Science, Tarbiat Modares University, Iran.

RAJABI, A. (2012): Ore controlling parameters and genesis of sedimentary exhalative $\mathrm{Zn}-\mathrm{Pb}$ (SEDEX type) deposits, Zarigan-Chahmir Area, East of Bafq, Central Iran.Ph.D. Thesis, Faculty of Science, Tarbiat Modares University, Iran.

RAJABI, A., RASTAD, E., ALFONSO, P. \& CANET, C. (2012): Geology, ore facies and sulfur isotopes of the Koushk vent-proximal sedimentary-exhalative deposit, Posht-e-Badam block, Central Iran.- Int. Geol. Rev., 54, 1635-1648.

RAJABI, A., CANET, C., RASTAD, E. \& ALFONSO, P. (2015): Basin evolution and stratigraphic correlation of sedimentary-exhalative $\mathrm{Zn}-\mathrm{Pb}$ deposits of the Early Cambrian Zarigan-Chahmir basin, Central Iran.- Int. Ore Geol. Rev., 64, 328-353.

RAMEZANI, J. \& TUCKER, R. (2003): The Saghand region, central Iran: U-Pb geochronology, petrogenesis and implications for Gondwana Tectonics.-American J. Sci., 303/3, 622-665. doi: 10.2475/ajs.303.7.622

REED, M.J., CANDELA, P.A. \& PICCOLI, P.M. (2000): The distribution of rare earth elements between monzogranitic melt and the aqueous volatile phase in experimental investigations at $800^{\circ} \mathrm{C}$ and $200 \mathrm{MPa}$.- Contrib. Mineral. Petrol., 140, 251-262.

SAMANI, B. (1993): Saghand formation, a riftogenic unit of upper Precambrian in central Iran.- Int. Geosci., 6, 32-45.

SAUNDERS, A.D., \& TARNERY, J. (1991): Back-arc basins.- In: FLOYD, P.A. (ed.): Oceanic Basalts. Blackie, Glasgow, 219-263. doi: 10.1007/978-1-4615-3540-9_10

SCHANDL, E.S., \& GORTON, M.P. (2002): Appplication of high field strength elements to discriminate tectonic setting in VMS environments.- Econ. Geol., 97, 629-642.

SIMON, A.C., PETTKE, T., CANDELA, P.A., PICCOLI, P.M. \& HEINRICH, C.A. (2004): Magnetite solubility and iron transport in magmatic-hydrothermal envi- 
ronments.- Geochim. Cosmochim. Acta, 68, 4905-4914. doi: 10.1016/j. gca.2004.05.033

SIMON, A.C., PETTKE, T., CANDELA, P.A., PICCOLI, P.M. \& HEINRICH, C.A. (2005): Gold partitioning in melt vapor-brine systems.- Geochim. Cosmochim. Acta, 69, 3321-3335. doi: 10.1016/j.gca.2005.01.028

SIMON, A.C., PETTKE, T., CANDELA, P.A., PICCOLI, P.M. \& HEINRICH, C.A. (2006): Copper partitioning in melt-vapor-brine-magnetite-pyrrhotite assemblage.Geochim. Cosmochim. Acta, 70, 5583-5600. doi: 10.1016/j.gca.2006.08.045

SMITH, R.E. \& SMITH, S.E. (1976): Comments on the use of Ti, Zr, Y, Sr, K, P and Na inclassification of basaltic magmas.- Earth and Plan. Sci. Lett., 32, 114-120.

STAMPFLI, G.M. (2009): Terranes Map of the Western Tethysides.- UNIL, University of Lausanne (open file).

STOSCH, H.G., ROMER, R.I., DALIRAN, F. \& RHEDE, D. (2011): Uranium-lead ages of apatite from iron oxide ores of the Bafq District, East-Central Iran.- Mineral. Deposita, 46, 9-21. doi: 10.1007/s00126-010-0309-4

SUN, S.S. \& MC DONOUGH, W.F. (1989): Chemical and isotopic systematics of oceanic basalts; implications for mantle composition and processes.- In: SAUNDERS, A.D. \& NORRY, M.J. (eds.): Magmatism in the Ocean Basins. London, UK, Geological Society of London, 313-345. doi: 10.1144/GSL.SP.1989.042.01.19

TAGHIPOUR, S., KANANIAN, A. \& SOMARIN, A.K.(2013): Mineral Chemistry and Alteration Parageneses of the Choghart Iron Oxide- apatite Occurrence, Bafq District, Central Iran.- Neues Jahrbuch für Geologie und Paläontologie, 269/3, 221-240.

TANATAR, I.I. (1925): New rocks of the Kryvy Rig iron ore basin: Part1.- Injenerny Rabotnik, 7.

TITAYEVA, N.A. (1994): Nuclear geochemistry.- CRC press, 304 p.
WILDE, A. (2013): Towards a model for albitite-type uranium.- J. Minerals, 3, 36-48. doi: $10.3390 / \min 3010036$

WINCHESTER, J.A. \& FLOYD, P.A. (1977): Geochemical discrimination of different magma series and their differentiation products using immobile elements.- Chem. Geol., 20, 325-343. doi: 10.1016/0009-2541(77)90057-2

WOOD, D.A. (1980): The application of a Th-Hf-Ta diagram to problems of tectonomagmatic classification and to establishing the nature of crustal contamination of basaltic lavas of the British Tertiary volcanic province.- Earth Planet. Sci. Lett., 50, $11-30$.

WOOD, S.A. (1990a): The aqueous geochemistry of rare earth elements and yttrium. 1. Review of available low-temperature data for inorganic complexes and the inorganic speciation of natural waters.- Chem. Geol., 82, 159-181.

WOOD, S.A. (1990b): The aqueous geochemistry of rare earth elements and yttrium. 2. Theoretical predictions of speciation in hydrothermal solutions to $350^{\circ} \mathrm{C}$ at saturation water vapor pressure.- Chem. Geol., 88, 99-125.

YAGHUBPUR, A. \& MEHRABI, B. (1997): Koushk Zinc-Lead Deposit a typical blackshale-hosted deposit in Yazd State, Iran.- J. Sci., I.R. Iran, 8/2, 117-125.

ZAJACZ, Z., CANDELA, P.A., PICCOLI, P.M., WALLE, M. \& SANCHEZ-VALLE, C. (2012): Gold and copper in volatile saturated mafic to intermediate magmas: Solubilities, partitioning, and implications for ore deposit formation.- Geochim. Cosmochim. Acta, 91, 140-159. doi: 10.1016/j.gca.2012.05.033

ZHOU, J.X. (1999): Geochemistry and Petrogenesis of Igneous Rocks Containing Amphibole and Mica: A Case Study of Plate Collision Involving Scotland and Himalayas.- Science Press, New York and Beijing, 41-72 